\title{
Multiscale variability in the Balearic Sea: An altimetric perspective
}

\author{
Evan Mason ${ }^{1}$ and Ananda Pascual ${ }^{1}$ \\ Received 25 July 2012; revised 6 May 2013; accepted 6 May 2013; published 17 June 2013.
}

[1] The present-day availability of an 18 year record of $1 / 8^{\circ}$ merged Mediterranean Sea sea level anomaly (SLA) data enables a contemporary description of long-term mesoscale activity in the Balearic Sea. SLA data from satellite altimetry are used to study the variability of sea level and surface geostrophic circulation at different spatial and temporal scales within this complex and relatively understudied region in the western Mediterranean (WMED). We find that the mean Northern Current along the Iberian slope is strongest in autumn, although higher variability in winter leads to stronger peaks in kinetic energy. The Balearic Current, which flows along the northern slopes of the Balearic islands, also has its maximum expression in autumn. Across the two Balearic channels (Ibiza and Mallorca), key locations that partly regulate meridional exchange in the WMED, observed seasonal variability in geostrophic velocity anomalies conforms rather well to prior descriptions, suggesting cautious confidence in the use of the Mediterranean merged altimeter product in nearshore regions. Circulation through the channels is maximum in winter. The channel data support the hypothesis that the channel circulation may be hindered by the intermittent presence of the Western Intermediate Water mass, which sometimes forms in winter in the Gulf of Lions. This is the first time that an analysis of variability in the Balearic channels has been performed using altimetric data.

Citation: Mason, E., and A. Pascual (2013), Multiscale variability in the Balearic Sea: An altimetric perspective, J. Geophys. Res. Oceans, 118, 3007-3025, doi:10.1002/jgrc.20234.

\section{Introduction}

[2] Knowledge of the circulation in the Mediterranean Sea and its multiple scales of variability that historically have proven difficult to uncouple has increased considerably over recent decades [Millot, 1999; Robinson et al., 2001; Millot and Taupier-Letage, 2005; Bergamasco and Malanotte-Rizzoli, 2011; Poulain et al., 2012a]. Merged data from satellite altimetry play an invaluable role [Larnicol et al., 2002; Pascual et al., 2002, 2007; Jordi et al., 2009; Amitai et al., 2010; Renault et al., 2012]. However, up to the present, there have been no long-term mesoscale variability studies focused on the Balearic Sea, which occupies a central position within the western Mediterranean (WMED) (Figure 1) and is described as a transition region between the northern (Gulf of Lions (GoL)) and southern (Algerian Sea) components of the so-called Western Basin cyclonic gyre [e.g., López García et al., 1994; Millot, 1999; Millot and Taupier-Letage, 2005]. Indeed, in comparison with these latter regions, the Balearic Sea experiences the largest temperature range over the annual cycle [López García and Camarasa Belmonte, 2011].

${ }^{1}$ IMEDEA (UIB-CSIC), TMOOS, Esporles, Palma de Mallorca, Spain.

Corresponding author: E. Mason, Mediterranean Institute for Advanced Studies (UIB-CSIC), C./Miquel Marquès 21, Esporles, Palma de Mallorca 07190, Spain. (emason@imedea.uib-csic.es)

(C2013. American Geophysical Union. All Rights Reserved. 2169-9275/13/10.1002/jgrc.20234
[3] In this paper, we use sea level anomaly (SLA) data obtained through satellite altimetry to describe the mean seasonal cycle of the Balearic Sea, and to identify and characterize its permanent, recurrent, and transient features. Recent altimetric studies that discuss the Balearic Sea include Birol et al. [2010] who examine variability of the Northern Current (NC) along the Franco-Iberian slope using along-track SLA data; and Jordi et al. [2009] who use remotely sensed surface chlorophyll-A (Chl-A) data in conjunction with altimeter SLA, finding that Chl-A distributions are strongly influenced by NC current modes near to Ibiza and also that, over the Ebre river shelf, Chl-A is more sensitive to Ebre outflow than to the basin circulation. Altimeter data have also been used to complement highresolution hydrographic data from gliders at the Catalan and Balearic fronts [Ruiz et al., 2009; Bouffard et al., 2010, 2012]; this approach is a promising new line of investigation for mesoscale and submesoscale studies, especially with the expected increases in nearshore altimeter resolution when the (SWOT) altimeter comes online in the next decade [Fu et al., 2010], although it will be many years before long-term variability studies become viable. As our stated interest is the variability, we choose to forgo the use of a synthetic mean dynamic topography (MDT) product such as RioMed [Rio et al., 2007], whose potential advantage over the SLA is the provision of absolute values, i.e., the absolute dynamic topography and associated geostrophic velocity. In the next section (section 2), we present a detailed description of the study region. In section 3 , we describe the SLA data, the processing methodology, and 


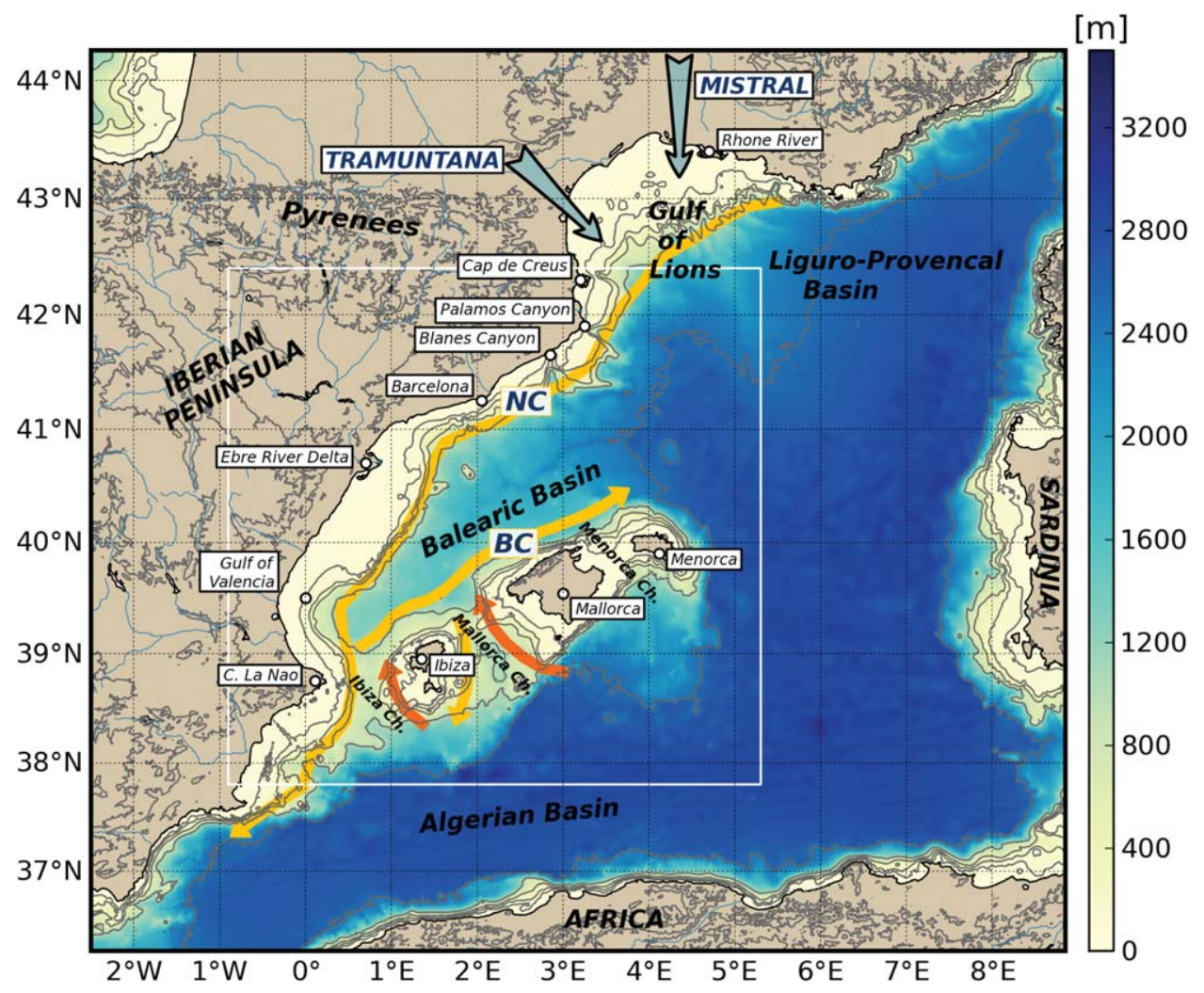

Figure 1. Map of the Balearic Sea study region (outlined in white) in the western Mediterranean Sea, showing the Balearic Islands and the Catalan and Valencian coastlines. Mean locations of the Northern (NC) and Balearic (BC) currents are depicted in yellow. Inflow (to the Balearic Sea) and outflow through the Ibiza and Mallorca channels is indicated by orange and yellow arrows, respectively. Isobaths are plotted at 100, 250, 500,1000 , and $2500 \mathrm{~m}$; land contours at 500,1000, and $2500 \mathrm{~m}$. The gridded topography is from the global 30 arc s database from the General Bathymetric Chart of the Oceans [ GEBCO, 2003].

supporting data. Long-term seasonal mean SLA and eddy kinetic energy (EKE) results are described and discussed in section 4, and followed up in section 5 with the corresponding interannual results. Our main conclusions are summarized in section 6 .

\section{Study Region}

[4] The Balearic Basin, relatively shallow at $<2500 \mathrm{~m}$, is bounded by the northern slopes of the Balearic Islands, and the Valencian and Catalan slopes (Figure 1). Zonal exchange between the basin and the adjacent LiguroProvençal Basin takes place through the open eastern margin, while meridional exchange is mediated by the island channels. The Algerian Basin to the south is deeper $(>2500 \mathrm{~m})$, larger, and less restricted than the Balearic Basin [Testor et al., 2005].

[5] Water masses within the WMED conform to the common three-layer structure of surface, intermediate, and deep waters. The dominant upper layer water mass (surface to $\sim 150-300 \mathrm{~m}$ ) consists of recirculating Atlantic Water (AW), which enters the Mediterranean through the Strait of Gibraltar and then takes multiple meandering pathways around the Mediterranean basin [Perkins and Pistek, 1990; Millot, 1999; Millot and Taupier-Letage, 2005]. AW properties are subject to modification through seasonal changes in the thermocline (induced by wind stress input and fluxes of heat and mass) [D'Ortenzio et al., 2005], cross-frontal mixing, and local input of freshwater from rivers.

[6] The intermediate layer consists of (i) a 150-600 m body of warm and salty Levantine Intermediate Water (LIW), which originates in the eastern Mediterranean; and (ii) Western Intermediate Water (WIW) which is sometimes formed during winter at the surface in the GoL under conditions of strong wind stress and low air temperature [Monserrat et al., 2008; Jordi and Hameed, 2009]. Cold but fresh WIW sinks to a relatively shallow neutral buoyancy level (at the base of the AW surface layer but overlying the LIW, i.e., $\sim 100-300 \mathrm{~m}$ ) and is advected along the Franco-Iberian coast to enter the Balearic Sea, eventually reaching the Balearic channels in spring/summer, where a potential temperature minimum $\left(\Theta<13^{\circ} \mathrm{C}\right)$ is usually indicative of its presence [Send et al., 1996; Millot, 1999; Pinot et al., 2002; Vargas-Yáñez et al., 2012]. Dense shelf water cascading events associated with canyons along the Catalan slope (e.g., the Blanes canyon) may also contribute to WIW production [Canals et al., 2006, 2009].

[7] The main WMED deepwater mass is a homogeneous deep layer of WMED deepwater (WMDW; $\Theta<12.9^{\circ} \mathrm{C}$ ) [e.g., Millot, 1999; Pinot and Ganachaud, 1999]. The 
production of WMDW that takes place in the GoL makes the WMED an especially important region of interest [Mediterranean Ocean Convective experiment (MEDOC), 1970; Marshall and Schott, 1999; Rixen et al., 2005; Canals et al., 2006; Testor and Gascard, 2006; Salat et al., 2010].

[8] The cyclonic circulation pattern within the Balearic Basin is mainly density driven, and is strongly constrained by steep bottom topography [Pinot et al., 1999]. The prograde (i.e., flowing with its cyclonic flank in deeper water) NC enters the domain from the east along the LiguroProvençal slope; the current displays marked seasonal variability, being strong in winter, but weakening in spring toward a summertime minimum [Castellón et al., 1990; Flexas et al., 2002; Pinot et al., 2002; Birol et al., 2010; Poulain et al., 2012b]. Variability of the current field is thought to be associated with variations of the thermohaline structure rather than with wind stress, which can be highly energetic over the shelf [Font, 1990]. At the Ibiza channel, characteristic NC modes have been identified, which can be associated with WIW presence/absence [Pinot and Ganachaud, 1999; Pinot et al., 2002; Heslop et al., 2012]. When anticyclonic lenses of WIW are present, they temporarily block the channel, forcing the NC eastward to feed into the Balearic Current (BC), which flows along the northern insular slopes [Pinot et al., 2002; Monserrat et al., 2008]. In the absence of WIW, the NC continues southward through the channel.

[9] The NC is associated with a slope front known as the Catalan front, which separates boundary (lighter) and interior (denser and older) varieties of the so-called old AW $(S \approx 38)$ [Font et al., 1988], which enters the domain from the GoL to the north and is found throughout the Balearic Basin. The Catalan front is generally discernible in sea surface temperature (SST) offshore of the Catalan coast to as far south as $41^{\circ} \mathrm{N}$, where the shelf widens near the Ebre delta [La Violette et al., 1990]. Mesoscale anticyclonic eddies near the Catalan shelf are not uncommon, especially in late summer and autumn [e.g., Rubio et al., 2005; Onken et al., 2008; Bouffard et al., 2010]; an extreme example is the anticyclone that occupied the Balearic Basin in 1998/ 1999 [Larnicol et al., 2002; Pascual et al., 2002].

[10] Recent AW, which is fresher and warmer than old $\mathrm{AW}$, enters the Balearic Basin domain from the south through the Balearic channels. The $\mathrm{BC}$ is associated with a frontal region, known as the Balearic front, that marks the division between recent and old AW [Font et al., 1988; La Violette et al., 1990; López García et al., 1994; Bouffard et al., 2010]. The salinity gradient across the Balearic front has recently been implicated in mesoscale eddy generation within the basin [Bouffard et al., 2012]. The North Balearic front can be seen as an eastward extension of the Balearic front [López García et al., 1994; Millot, 1999]. The meridional position of the Balearic/North Balearic front is primarily related to salinity rather than temperature gradients. Seasonal surface heating in summer and autumn produces thermal fronts at the surface as far north as $42^{\circ} \mathrm{N}$; the Pyrenees front is a named example that, in summer, extends offshore from the Catalan coast between $\sim 41^{\circ}$ and $42^{\circ} \mathrm{N}$ [López García et al., 1994]. The front arises as a result of contrasting surface heating in the wind-sheltered lee of the Pyrenees mountain range, and cooling and deepening of the mixed layer owing to intense mixing by northwesterly wind stress over the western GoL.

[11] Wind stress patterns over the WMED are strongly influenced by the episodic Mistral and Tramuntana winds (shown schematically in Figure 1) [Jansá, 1987; Zecchetto and De Biasio, 2007; Chronis et al., 2011], with the GoL having the highest probability of high wind speeds $(>10 \mathrm{~m}$ $\mathrm{s}^{-1}$ ) in the Mediterranean. In the adjacent Balearic Sea, winds are less intense and more variable, with slight dominance of westerly winds in winter and spring, easterly winds in summer, and easterly/northeasterly winds in autumn [Dorman et al., 1995; Palomares Losada, 1999; Chronis et al., 2011]. The differing wind stress characteristics between the Balearic Sea and the GoL lead to the generation of significant anticyclonic wind stress curl over the eastern part of the Balearic Sea. In a modeling study, Molcard et al. [2002] stressed the relation between wind stress curl and the gyres and subgyres that are characteristic of the Mediterranean circulation [e.g., Millot and Taupier-Letage, 2005].

[12] Two major Mediterranean rivers, the Rhone and the Ebre, empty into the WMED [Dai and Trenberth, 2002]. Riverine freshwater from the Ebre river is known to modify the position of the NC following periods of high discharge [Font et al., 1990; Salat et al., 2002; Xing and Davies, 2002a, 2002b]. The Rhone, which empties into the GoL, is an important remote freshwater source for the Balearic Sea [e.g., La Violette et al., 1990; Masó and Tintoré, 1991].

\section{Data and Methods}

\subsection{Altimetric Data}

[13] We use 18 years (January 1993 to December 2010) of weekly averaged delayed-time Mediterranean reference SLA data supplied by Archiving, Validation and Interpretation of Satellite Oceanographic data [AVISO, 2012], which combine data from the TOPEX/Poseidon, ERS-1, ERS-2, Jason-1, Envisat, and OSTM/Jason-2 altimeter missions. The SLA data are gridded on a regular $1 / 8$ grid that covers the entire Mediterranean Sea [Pujol and Larnicol, 2005].

[14] Satellite-borne altimeters measure the sea surface height (SSH), which is the difference between the height of the altimeter $(S)$ and a reference ellipsoid $(R): S S H=S-R$. Inherent to the SSH measurement are contributions from the geoid and the dynamic topography, where the latter signal can be decomposed into a permanent part and a highly variable part. Ideally, one can estimate the dynamic topography by removing the geoid. However, owing to ongoing uncertainty in the shape of this equipotential surface, the variable part of the signal in the AVISO SLA product is instead obtained by subtracting a 7 year SSH reference mean (based on the time period $P=1993-1999)$ from the altimeter-measured SSH, i.e., $S L A_{1993-1999}=S S H-$ $<S S H_{1993-1999}>$, with the implied assumption that the geoid is constant over this period of time.

[15] In this study, we adjust the AVISO SLA to form anomalies with respect to an 18 year reference mean that corresponds to our period of interest $(P=1993-2010)$ using

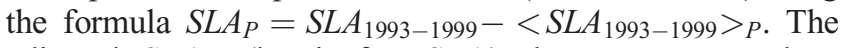
adjusted $\operatorname{SLA}_{P}$ (hereinafter SLA) data are averaged to 
produce seasonal and annual means for (i) each individual year and (ii) the full-time record (i.e., 1993-2010). The winter season is defined by the months January to March, and so on for spring, summer, and autumn.

[16] A corresponding record of the surface EKE, a bulk measure of mesoscale variability, is calculated from the SLA. Assuming geostrophy, the EKE per unit mass is computed as $E K E=\frac{1}{2}\left[U_{g}^{\prime 2}+V_{g}^{\prime 2}\right]$, where $U_{g}^{\prime}=-\frac{g}{f} \frac{\partial \eta^{\prime}}{\partial y}$ and $V_{g}^{\prime}=\frac{g}{f} \frac{\partial \eta^{\prime}}{\partial x}$ are the respective sea surface geostrophic velocity anomalies (GVA), $g$ the gravitational acceleration, $f$ the local Coriolis parameter and, lastly, three-point-stencil finite differencing over latitude $(y)$ and longitude $(x)$ leads to the derivatives $\frac{\partial \eta^{\prime}}{\partial y}, \frac{\partial \eta^{\prime}}{\partial x}$.

[17] A possible source of error in our work is the use of the three-point stencil (rather than five or seven points) for the geostrophic velocity calculations [Arbic et al., 2012]. However, given that our objective is to describe variability rather than absolute values, we do not feel our results are unduly compromised by this choice. To support the validity of the geostrophic approximation within the study region, we note that the Rossby number $(R o)$ for the $\mathrm{NC}$ is small; for example, Flexas et al. [2002] estimated $R o=\sim 0.16$ for a typical NC surface speed $U=\sim 50 \mathrm{~cm} \mathrm{~s}^{-1}$, width $L=\sim 30$ $\mathrm{km}$, and $f=\sim 10^{-4} \mathrm{~s}^{-1}$.

[18] Confidence intervals (95\%) for the sample mean of the SLA and EKE at each point in space are calculated using a Student's $t$ distribution following von Storch and Zwiers [1999] (section 4.6). The standard formula for the confidence interval is $\pm s_{2}(x, y) a / \sqrt{n^{\star}}$, where $s_{2}(x, y)$ is the respective SLA/EKE sample standard deviation in space; $a=q_{t}\left(\alpha, n^{*}\right)$ is here specified as the percentage point, $2.5 \%(\alpha=0.025)$ for two-tailed SLA and 5\% $(\alpha=0.05)$ for one-tailed EKE, of the $t$ distribution with $n^{\star}-1$ degrees of freedom; and $n^{\star}$ is the estimated number of independent SLA/EKE observations in the respective sample means. Given weekly data maps based upon $\sim 10$ day repeat cycles of the satellite altimeters and the assumption that $\sim 20$ days between observations is sufficient for independence, we estimate $n^{\star}=7 / 20 \times n$ with $n$ as the sample size.

\subsection{Supplementary Data}

[19] Wind vector data from the cross-calibrated multiplatform (CCMP) long-term satellite global ocean surface wind data set of Atlas et al. [2011] are used in section 4.5 to create a Balearic Sea seasonal wind stress climatology spanning the 1993-2010 AVISO SLA period. The $10 \mathrm{~m}$ CCMP wind data are six hourly with a horizontal resolution of $25 \mathrm{~km}$ and presently span the period 1987-2010. Wind stress is computed following Smith [1988]. Variance ellipses of the wind stress are calculated following Preisendorfer [1988].

[20] Daily mean air temperature data at $1000 \mathrm{mb}$ are used in section 5.2.1 to create an index of WIW formation in the GoL (the IDEA index; Monserrat et al. [2008]). The data are obtained from the global $2.5^{\circ}$ National Centers for Environmental Prediction-National Center for Atmospheric Research (NCEP-NCAR) reanalysis [Kalnay et al., 1996] for the period 2 January 1948 to 1 February 2012. Monthly mean river Ebre outflow data for the period 2003-2010 presented in section 5.2.2 were downloaded from the website of the Sistema Automático de Información Hidrológica (SAIH) de la Cuenca Hidrográfica del Ebro. Bathymetry data for the WMED Sea used in several of the figures are taken from the General Bathymetric Chart of the Oceans [GEBCO, 2003].

\section{Seasonal Variability}

\subsection{Seasonal Mean SLA}

[21] Figure 2 shows seasonal mean SLA and associated geostrophic velocity anomalies (GVA) in the Balearic Sea. To facilitate the observation of dynamical features, the spatial average corresponding to each seasonal SLA mean is removed. This process largely removes steric height effects, which are a major contributor to Mediterranean Sea surface elevation [Larnicol et al., 1995]. The amplitude range of the resulting mean SLA is about $5 \mathrm{~cm}$.

\subsubsection{Winter}

[22] In winter, large prograde GVA vectors along $\sim 42^{\circ} \mathrm{N}$ depict an intensified $\mathrm{NC}$ that is associated with a dominant positive meridional mean SLA gradient (Figure 2a). This gradient is chiefly maintained by a large cyclonic SLA node, hereinafter referred to as the Provençal Cyclonic Gyre (PCG), located south of the GoL at the eastern boundary of the Balearic Sea $\left(\sim 41.3^{\circ} \mathrm{N}, 4.8^{\circ} \mathrm{E}\right)$. A second, smaller, cyclonic node lying near the Blanes canyon acts to steer the NC inshore toward the Catalan shelf. However, west of the canyon, GVA vectors over the shelf become smaller and cross-shelf SLA gradients flatten, indicating a drop in the intensity of the NC toward its annual mean values. In part, this weakening is explained by the Blanes cyclonic node that, in association with the PCG, directs an eastward GVA flow away from the shelf and across the center of the Balearic Basin at $\sim 40.7^{\circ} \mathrm{N}$, to as far east as Menorca. At the Ebre slope, the wintertime NC continues unimpeded, as indicated by still weak cross-shelf SLA gradients and GVA vectors. Further south however, at the Gulf of Valencia, the winter NC is accelerated through the eastern part of the Ibiza channel by a cyclonic SLA node located just north of Ibiza. This node, in concert with an anticyclonic SLA node lying northwest of Mallorca, induces a contrasting northward flow anomaly through the Mallorca channel. While the cyclonic node may accelerate the BC toward Mallorca, the anticyclonic node may severely disrupt the progress of this current across the channel. Over the southern insular slopes, meridional SLA gradients are positive, and the flow anomaly acts counter to the northeastward mean insular flow.

\subsubsection{Spring}

[23] The springtime SLA pattern north of the Ebre is quite similar to the winter pattern (Figure 2b). The NC, still in association with the aforementioned PCG and Blanes cyclonic SLA nodes, crosses the Catalan slope at the same latitude $\left(\sim 41.7^{\circ} \mathrm{N}\right)$ as in winter. However, the position of its offshore axis near the GoL has shifted slightly to the south as a consequence of a weakening PCG. The changing PCG induces a change in orientation, from eastward to southeastward, of the axis of the winter offshore flow anomaly that originates near the Blanes canyon. South of the Ebre the springtime patterns diverge from the winter situation. Along the Valencian slope, retrograde (i.e., current flow with the cyclonic flank in shallower water) GVA 


\section{AVISO MSLA}

(a) Winter

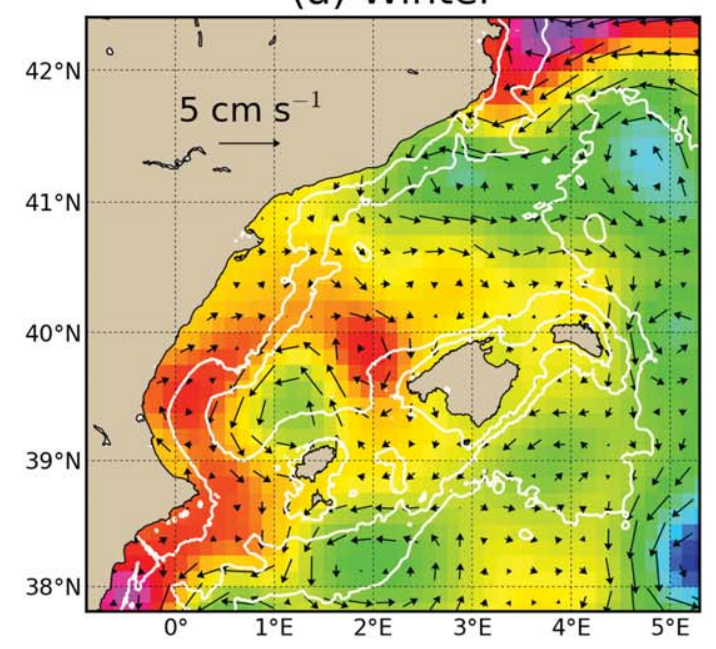

(c) Summer

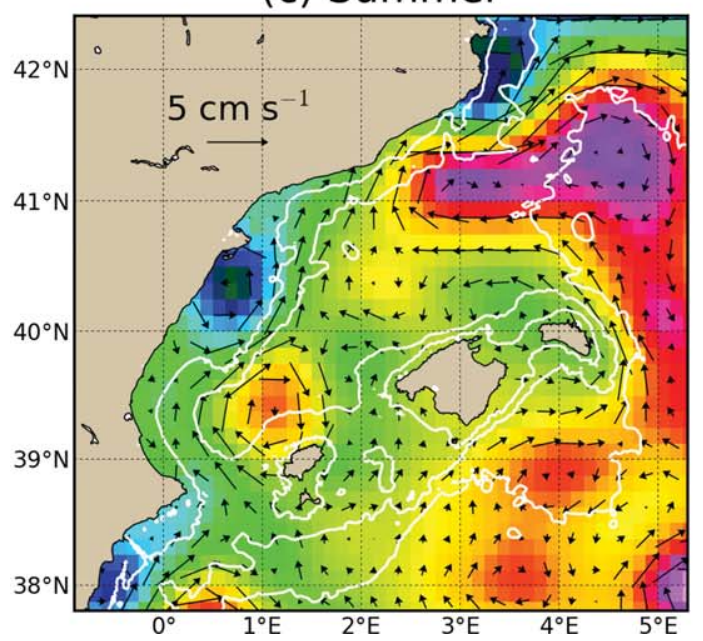

(b) Spring

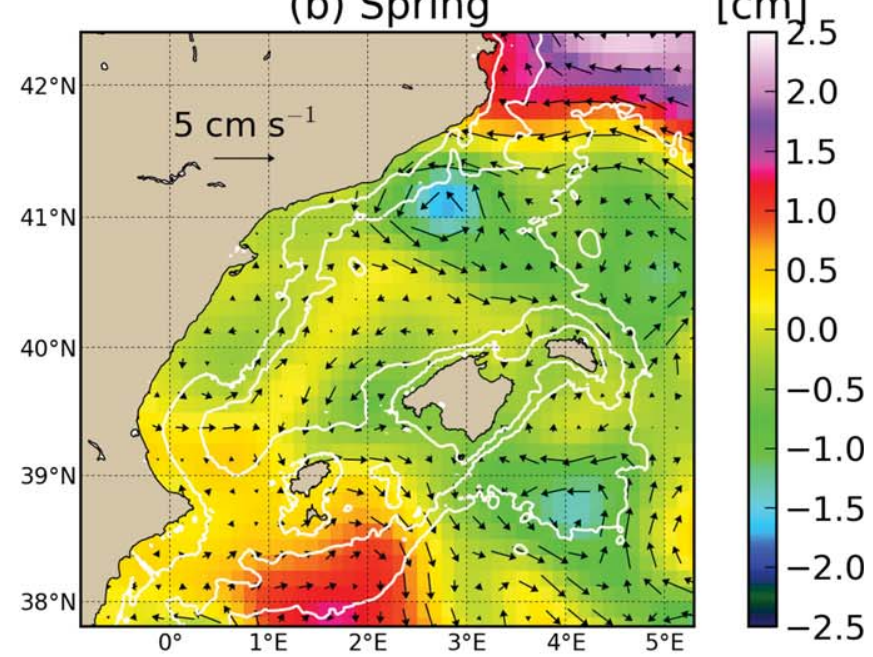

(d) Autumn

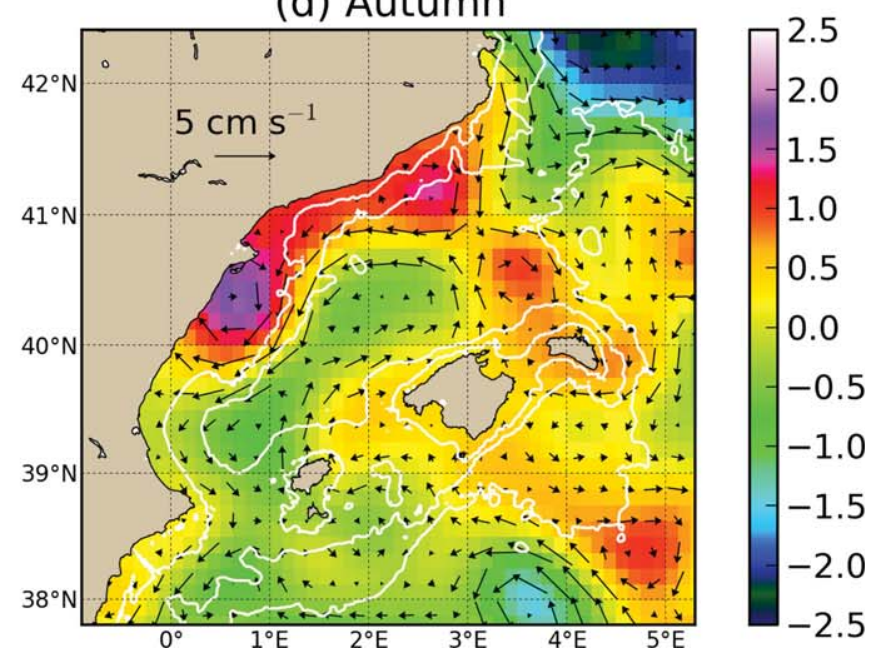

Figure 2. Seasonal mean sea level anomalies and GVA vectors in the Balearic Sea. Note that the spatial average corresponding to each seasonal SLA mean has been removed. Isobaths are plotted in white at 100, 1000, and $2500 \mathrm{~m}$.

vectors and a positive zonal SLA gradient indicate a weakening of the $\mathrm{NC}$ with respect to annual mean values. However, a half degree to the east, the SLA gradient becomes negative, inducing a flow anomaly in the center of the Balearic Basin directed toward Ibiza. A negative SLA gradient across the Mallorca channel implies a southward flow anomaly in spring, as well as weakening of the BC. A strong positive SLA gradient across the southern Ibiza slope indicates significant reinforcement of the annual mean eastward flow. There is a change of the circulation anomaly (anticyclonic to cyclonic) through both the Mallorca and Menorca channels.

\subsubsection{Summer}

[24] The mean SLA summer pattern depicted in Figure $2 \mathrm{c}$ can be generally seen as the inverse of the wintertime situation, such that the associated flow anomalies oppose the annual mean circulation (Figure 1), resulting in a rather weak summertime circulation. For example, along much of the axis of the $\mathrm{NC}$ strong retrograde GVA vectors act in opposition to the annual mean (prograde) current. The largest NC GVA vectors are found south of the GoL at $\sim 41.7^{\circ} \mathrm{N}$, where an intense negative meridional SLA gradient is associated with the summertime PCG. As in wintertime, a second SLA node is present near the Blanes canyon, but in summer, the anomaly is anticyclonic rather than cyclonic. Further south over the Ebre shelf and Gulf of Valencia, the NC is further impeded by a dipole-like circulation anomaly: an intense cyclonic SLA node is situated over the shelf just south of the Ebre river mouth (note that this feature has no counterpart in the winter SLA); meanwhile, north of Ibiza there is an anticyclonic SLA node (its counterpart is the winter cyclonic node in Figure 2a). In the Ibiza channel, GVA vectors are directed northward. The $\mathrm{BC}$ is also suppressed in summer, particularly over the northern Ibiza slope, when accounting for the abovementioned anticyclonic node. The cross-basin eastward current anomaly described in winter and spring is vigorously opposed in summer; strong positive meridional and zonal 
SLA gradients seen north and west of Mallorca and Menorca, respectively, are associated with the PCG and Blanes canyon anomalies, and also the summertime entrance to the Balearic Sea domain of Algerian anticyclones from the south [e.g., Perkins and Pistek, 1990; Testor et al., 2005]. In contrast to the situation in the Balearic Basin, northeastward flow anomalies along the southern insular slopes reinforce the annual mean geostrophic circulation.

\subsubsection{Autumn}

[25] The autumn SLA transition is abrupt with marked changes throughout the domain (Figure 2d). Strong prograde GVA vectors, associated with the development of an intense negative across-slope SLA gradient along the entirety of the Catalan and Valencian slopes, act to strengthen the NC; apparently, these mean flow anomalies exceed the winter values. The summertime PCG node is gone, although a negative meridional gradient, associated with strong decreases in the SLA toward the GoL, persists. Southward GVA vectors off Cap de Creus are induced by a negative zonal SLA gradient. In contrast to summer, an intense anticyclonic SLA node occupies the Ebre shelf. The $\mathrm{BC}$ along the northern insular slope is enhanced by a negative cross-slope gradient. However, at around $3^{\circ} \mathrm{E}$, the $\mathrm{BC}$ is diverted northward, partly under the influence of an anticyclonic SLA node situated north of the Menorca channel at $\sim 40.5^{\circ} \mathrm{N}$. We note that this node occupies the winter position of the intense 1998 anticyclone described by Pascual et al. [2002]; in section 5.4, we examine if this feature's existence in the autumn SLA is solely related to the 1998 anticyclone. Along the southern insular slopes, there are no significant cross-slope gradients, such that the annual mean flow can be considered dominant. In contrast to spring, weak positive zonal gradients are found across the Mallorca and Menorca channels, implying northward (anticyclonic) flow anomalies.

\subsection{Ibiza and Mallorca Channels}

[26] The Ibiza and Mallorca channels are important locations of exchange between the Balearic and Algerian Basins (section 2). While Figure 2 is suggestive about their seasonality, probability density functions (PDF) of the seasonal mean GVA across the channels (Figures 3 and 4) are more informative. Means of GVA vectors normal $\left(\mathrm{GVA}_{\perp}\right)$ to transects across each channel (after a rotation of the components) are taken at each time step. Bins are spaced every $0.025 \mathrm{~m} \mathrm{~s}^{-1}$ and span the range $\pm 0.15 \mathrm{~m} \mathrm{~s}^{-1}$. Three time periods are calculated: (i) the full measurement period (1993-2010), (ii) the first half (1993-2001), and (iii) the second half (2002-2010); the two subsets provide a basic measure of sampling sensitivity. A summary of the Ibiza and Mallorca statistics can be found in Table 1.

[27] PDFs of $\mathrm{GVA}_{\perp I C}$ at the $80 \mathrm{~km}$ Ibiza channel in Figure 3 confirm rather well the established seasonal mean circulation (section 2). The probability of negative (southward) $\mathrm{GVA}_{\perp I C}$ exceeding positive (northward) $\mathrm{GVA}_{\perp I C}$ is true in winter, spring, and autumn. The greatest (smallest) range of the magnitude of $\mathrm{GVA}_{\perp I C}$ occurs in winter (summer); this equates to higher probabilities for strong anomalies in winter and vice versa in summer. The PDFs demonstrate the large variability that has previously been observed in the channel [e.g., García-Lafuente et al., 1995;

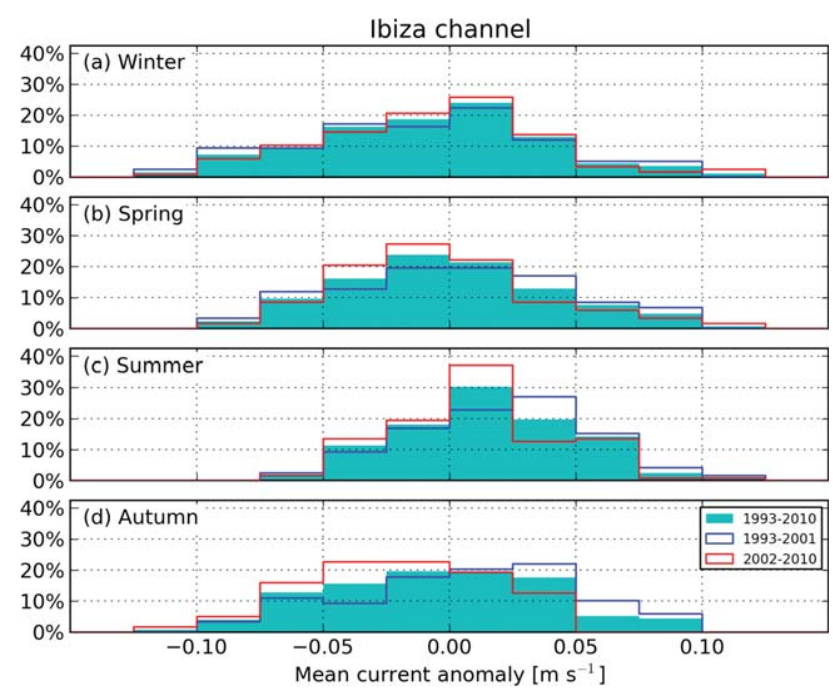

Figure 3. Seasonal PDFs of meridional surface geostrophic velocity anomalies $\left(\mathrm{GVA}_{\perp I C}\right)$ through the Ibiza channel. See $n$ in Table 1 for sample sizes. Three time ranges are sampled: 1993-2010 (turquoise, filled), 1993-2001 (blue), and 20022010 (red).

Pinot et al., 2002; Heslop et al., 2012], with significant probabilities for both positive and negative $\mathrm{GVA}_{\perp I C}$ in each season. With respect to the sampling period, the wintertime shows little change between 1993-2001 and 2002-2010. In summer, northward flow intensity (positive $\mathrm{GVA}_{\perp I C}$ ) is seen to decrease in the second period. In spring and autumn there are also second period decreases in northward flow intensity but, unlike summer, there are also corresponding increases in southward flow intensity (negative $\left.\mathrm{GVA}_{\perp I C}\right)$.

[28] PDFs of $\mathrm{GVA}_{\perp M C}$ at the $70 \mathrm{~km}$ Mallorca channel are presented in Figure 4. In comparison with $\mathrm{GVA}_{\perp I C}$

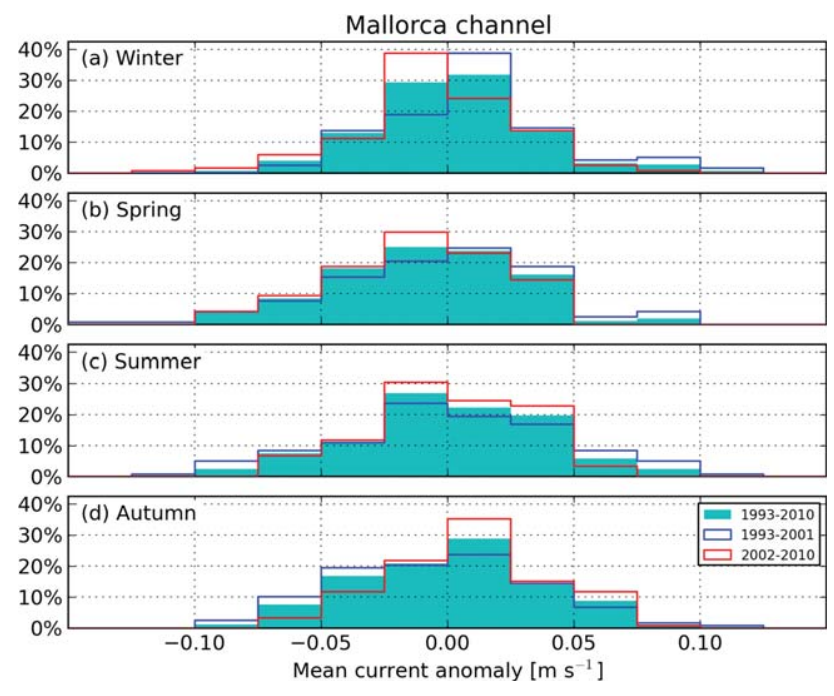

Figure 4. Seasonal PDFs of meridional surface geostrophic velocity anomalies $\left(\mathrm{GVA}_{\perp M C}\right)$ through the Mallorca channel. See $n$ in Table 1 for sample sizes. Three time ranges are sampled: 1993-2010 (turquoise, filled), 19932001 (blue), 2002-2010 (red). 
Table 1. Seasonal Means of the 1993-2010 Flow Anomalies Through the Ibiza Channel (GVA $\perp I C$, Shown in Figure 3) and the Mallorca Channel (GVA $\perp M C$, Shown in Figure 4) ${ }^{\mathrm{a}}$

\begin{tabular}{|c|c|c|c|c|c|c|c|c|}
\hline & Winter & Spring & Summer & Autumn & Winter & Spring & Summer & Autumn \\
\hline & \multicolumn{4}{|c|}{ Ibiza Channel } & \multicolumn{4}{|c|}{ Mallorca Channel } \\
\hline Mean & -0.7 & 0 & 1.6 & -0.5 & 0.2 & -0.8 & 0.2 & 0.1 \\
\hline Mean north & 3.1 & 3.4 & 3.4 & 3.4 & 2.6 & 2.7 & 3.2 & 2.9 \\
\hline Mean south & 4.1 & 3.2 & 2.4 & 3.9 & 2.4 & 3.5 & 3.0 & 3.0 \\
\hline$n$ & 245 & 247 & 237 & 249 & 245 & 247 & 237 & 249 \\
\hline
\end{tabular}

${ }^{\mathrm{a}} n$ denotes the respective sample sizes. Units are given in $\mathrm{cm} \mathrm{s}^{-1}$.

(Figure 3), GVA $\perp M C$ have smaller ranges, hence generally weaker flow anomalies. Over the full measurement period, spring, summer and autumn show a slight dominance of negative $\mathrm{GVA}_{\perp M C}$ while, in winter, the $\mathrm{GVA}_{\perp M C}$ profile is roughly symmetric. The winter period shows some sensitivity to the sampling period; this is most visible for smaller anomalies $\left(-0.25<\mathrm{GVA}_{\perp M C}<0.25 \mathrm{~m} \mathrm{~s}^{-1}\right)$, with a northward (southward) tendency during 1993-2001 (20022010), but is evident for larger $\mathrm{GVA}_{\perp M C}$ values too. In summer, there is a decrease in the probability of stronger $\mathrm{GVA}_{\perp M C}$ during the second period. The autumn sees a tendency for weaker (stronger) negative (positive) $\mathrm{GVA}_{\perp M C}$ in the second period; this is opposite to the autumn situation in the Ibiza channel (cf. Figure 3d).

\subsection{Northern Current}

[29] Figure 2 shows the NC to have a strong seasonal character, with strong (weak) flows in winter (summer). This cycle is especially notable in the region of the intense meridional SLA gradient at $\sim 42^{\circ} \mathrm{N}$, which corresponds to the position of the (summertime) Pyrenees front (section 2 ), where wind induced cooling north of the front in summer leads to lowering of the sea level within the GoL [López García et al., 1994; Olita et al., 2011]. However, with respect to the intensity of the $\mathrm{NC}$ along the Catalan and Valencian slopes, in Figure 2 we observed maximum prograde GVA (hence strengthening of the NC with the respect to the annual mean geostrophic velocity) in the autumn mean rather than the winter mean. This observation is in agreement with current meter data collected near the Ebre shelf break [Font et al., 1990; Send et al., 1999], and also along-track SLA data reported by Birol et al. [2010], who found that the peak NC flow straddled the autumnwinter transition. Nevertheless, the present data also show that at the Ibiza channel the probability of stronger prograde current anomalies is slightly higher in winter than in autumn, as evidenced by comparing winter and autumn $\mathrm{GVA}_{\perp I C}$ (Figures $3 \mathrm{a}$ and $3 \mathrm{~d}$ ). This observation is especially pronounced in years without WIW; cf. Figures 11a and $11 \mathrm{~d}$, discussed in section 5.2.1 below.

\subsection{Provençal Cyclonic Gyre}

[30] The PCG is a robust feature in the long-term seasonal SLA of Figure 2 (section 4.1 above, but see also section 5.4 below). Its alignment with the $2500 \mathrm{~m}$ isobath in Figures $2 \mathrm{a}$ and $2 \mathrm{c}$ suggests a degree of topographic steering, which in turn implies a significant barotropic component to the flow. Deep barotropic flows have been observed using floats and current meters in the Algerian Basin by
Testor et al. [2005], who describe the cyclonic (Eastern and Western) Algerian Gyres as being permanent barotropic features that are dominant at deep and intermediate layers. Testor et al. [2005] stress the role played by closed $f / H$ isocontours ( $H$ is depth) on the gyre circulations, and argue that the gyres are forced through lateral diffusion of kinetic energy and potential vorticity from the boundary circulation, i.e., the eastward Algerian Current and associated instabilities (Algerian eddies) flowing eastward (northward) along the north African (west Sardinian) coast. Aside from closed $f / H$ isocontours, these conditions are arguably applicable to the northwestern basin and, hence, to the existence of a barotropic gyre centered around $\sim 41.3^{\circ} \mathrm{N}, 4.8^{\circ} \mathrm{E}$. We note that the cyclonic circulations in these basins (Algerian and Provençal) are also in accord with the Neptune effect [e.g., Holloway, 2008; Holloway et al., 2011], that has previously been invoked by Álvarez et al. [1994] to explain the annual mean cyclonic flow within the Balearic Basin. As well as a tendency for currents to follow topographic contours, Neptune is associated with a preferred sense of direction, namely, shallow to the right in the northern hemisphere [Holloway et al., 2011].

\subsection{Seasonal EKE}

[31] The seasonal cycle of the mean EKE in the Balearic Sea is shown in Figure 5. A previous merged altimetric study suggested that surface EKE in the northwestern basin is generally weak in comparison with the southern Mediterranean [Pascual et al., 2007]. This pattern is evident within the study domain irrespective of the season: higher EKE $\left(>100 \mathrm{~cm}^{2} \mathrm{~s}^{-2}\right)$ is found towards the eastern end of the Algerian Basin where Algerian eddies enter from the southeast and populate the southern Balearic Sea [Perkins and Pistek, 1990; Millot, 1999; Puillat et al., 2002; Testor et al., 2005].

[32] Over the Balearic Basin as a whole, the highest EKE is found in autumn (Figure 5d). In winter, EKE drops off sharply (Figure 5a) and by the springtime (Figure $5 \mathrm{~b}$ ) it is at its lowest levels (cf. spring MSLA in Figure 2b). It is noteworthy that EKE across the Ibiza channel is generally low in all seasons.

[33] Three locations within the basin contain EKE of over $50 \mathrm{~cm}^{2} \mathrm{~s}^{-2}$ throughout the year. The first, at the northern Ibiza slope, peaks at around $70 \mathrm{~cm}^{2} \mathrm{~s}^{-2}$ in spring and summer (Figures $5 \mathrm{~b}$ and $5 \mathrm{c}$ ). The other two peaks are found near the peninsula: at the steepest part of the Valencian slope $\left(\sim 39.8^{\circ} \mathrm{N}, 0.9^{\circ} \mathrm{E}\right)$, where EKE exceeds $80 \mathrm{~cm}^{2} \mathrm{~s}^{-2}$ in autumn (Figure 5d); and near to the Blanes canyon $\left(\sim 41^{\circ} \mathrm{N}, 3^{\circ} \mathrm{E}\right)$, where EKE exceeds $100 \mathrm{~cm}^{2} \mathrm{~s}^{-2}$ in summer 


\section{AVISO EKE (seas)}
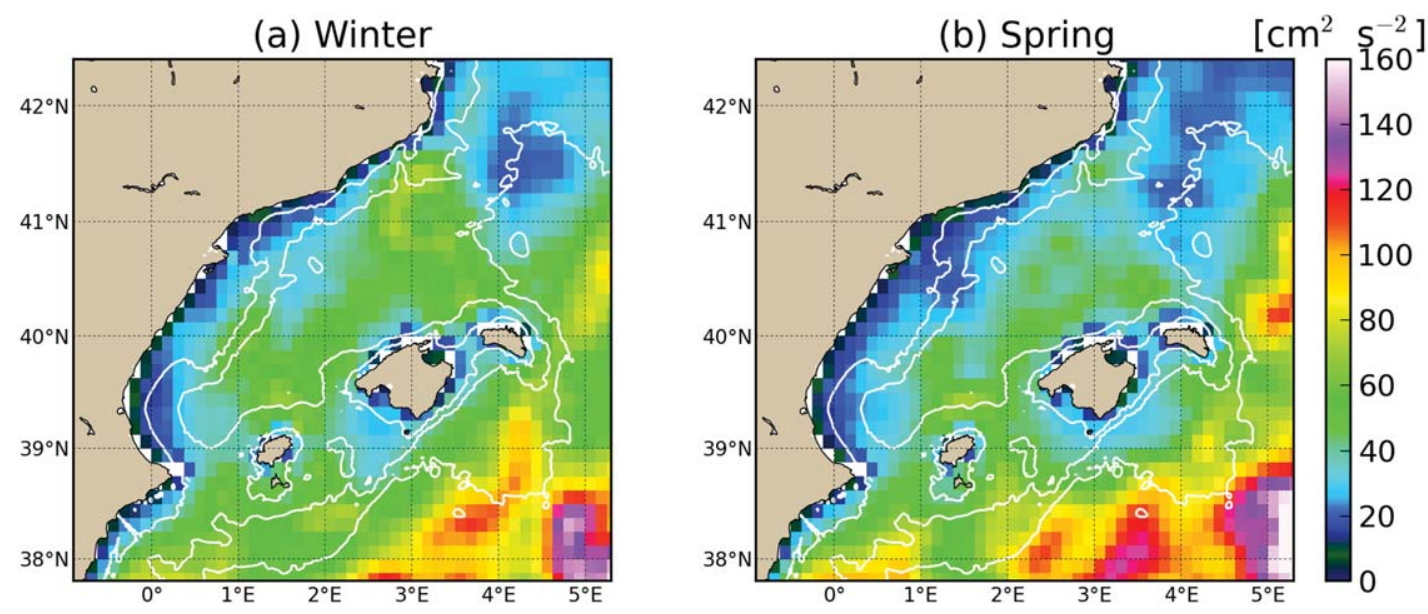

(c) Summer

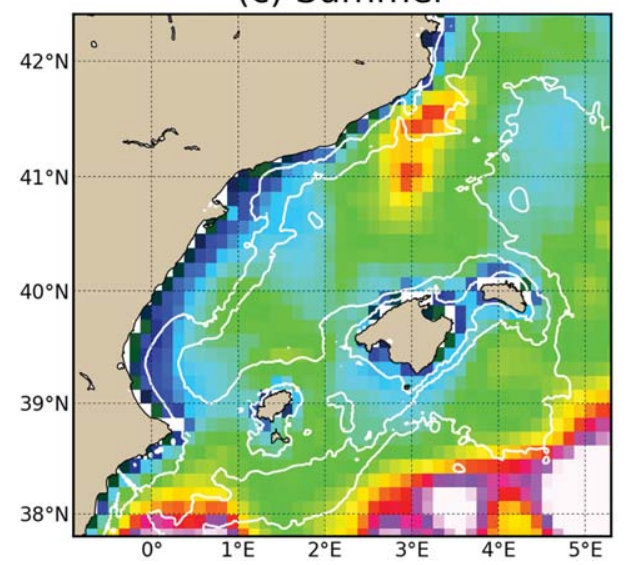

(d) Autumn

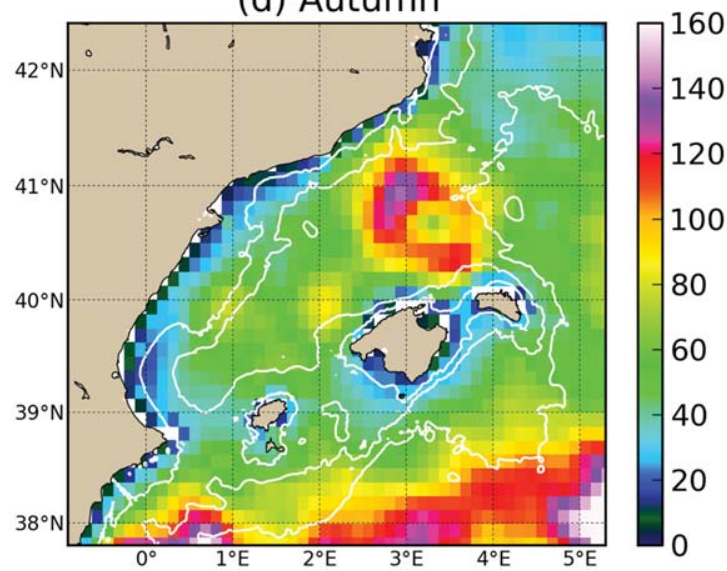

Figure 5. Seasonal mean EKE in the Balearic Sea. Isobaths are plotted in white at 100, 1000, and $2500 \mathrm{~m}$.

and autumn, taking the form of large irregularly shaped patches found towards the centre of the basin.

[34] Mesoscale activity at seasonal timescales within the WMED has been linked to the annual cycle of the wind stress [Pujol and Larnicol, 2005], which generally peaks in winter. However, the frequency of episodic extreme wind events (wind speeds $>20 \mathrm{~m} \mathrm{~s}^{-1}$ ) in the Balearic Sea has been shown by Chronis et al. [2011] to peak in late summer and autumn, being nearly double that of the winter count. Evidence in support of Chronis et al.'s observations can be seen in Figure 6, where we show seasonal means of CCMP-derived wind stress, wind stress curl, and wind stress variance ellipses over the study domain. The dominant winter and autumn patterns are illustrated, both over the Balearic Sea where nearly circular wind stress ellipses indicate high directional variability, and the GoL where stress ellipses are more anisotropic with major axes approximately aligned with the Mistral and Tramuntana. Weakly anisotropic stress ellipses over the Ebre shelf are aligned in the offshore direction in winter and autumn, in correspondence with the Mistral [García, 1982; Espino et al., 1998].

[35] The directionally unstable episodic extreme winds in autumn over the Balearic Sea can be expected to energize the surface layers, through disruption of the weakening thermocline and the promotion of vertical mixing. Spatial nonuniformity of the wind stress curl induces local upwellings and downwellings that further contribute to a dynamic upper ocean [Chelton et al., 2004].

[36] The seasonal cycle of EKE within the Balearic Basin, viz., EKE peaks in autumn and troughs in spring, described in Figure 5 is similar to what has been observed at diverse locations outside of the Mediterranean Sea; for example, in the region of the Argentinian shelf [Capet et al., 2008a], at the Canary Islands [Mason, 2009], and offshore of Peru and Chile [Colas et al., 2012]. The latter authors link EKE variability offshore (beyond the coastal upwelling) of Peru and Chile with surface frontogenesis [e.g., Capet et al., 2008b], which they diagnose using PDFs of modeled and observed SST gradients. We can speculate that there is a similar link between temporal variability in frontal activity and EKE in our study region, but further investigation is beyond the scope of this study. We note however that spatial variability of SST in the Balearic Sea has been found to be maximum in autumn, with low values in winter and spring [López García and Camarasa Belmonte, 2011].

[37] The deepwater region just south of the Blanes canyon $\left(41^{\circ} \mathrm{N}, 3^{\circ} \mathrm{E}\right)$ has a particularly dynamic and variable 


\section{CCMP wind stress and curl}

(a) Winter

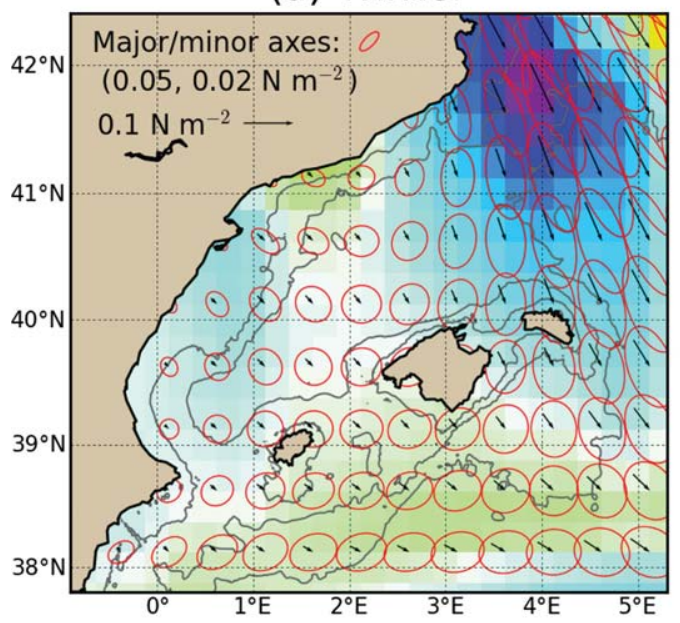

(c) Summer

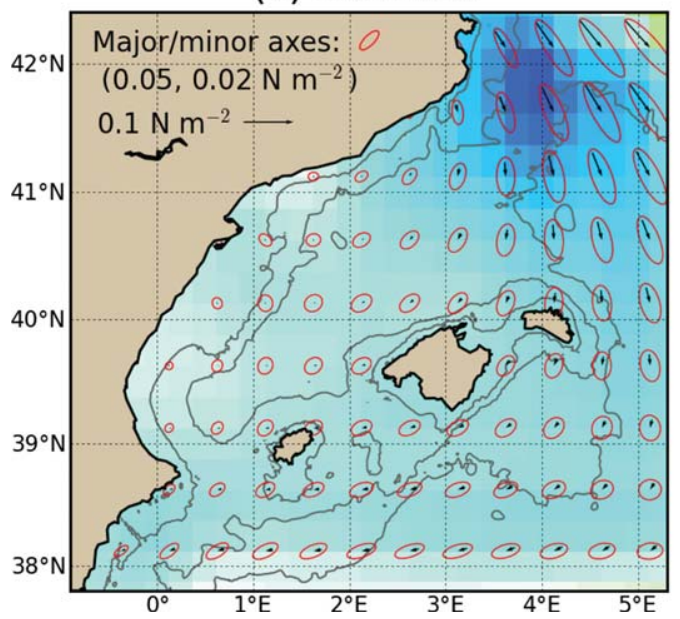

(b) Spring

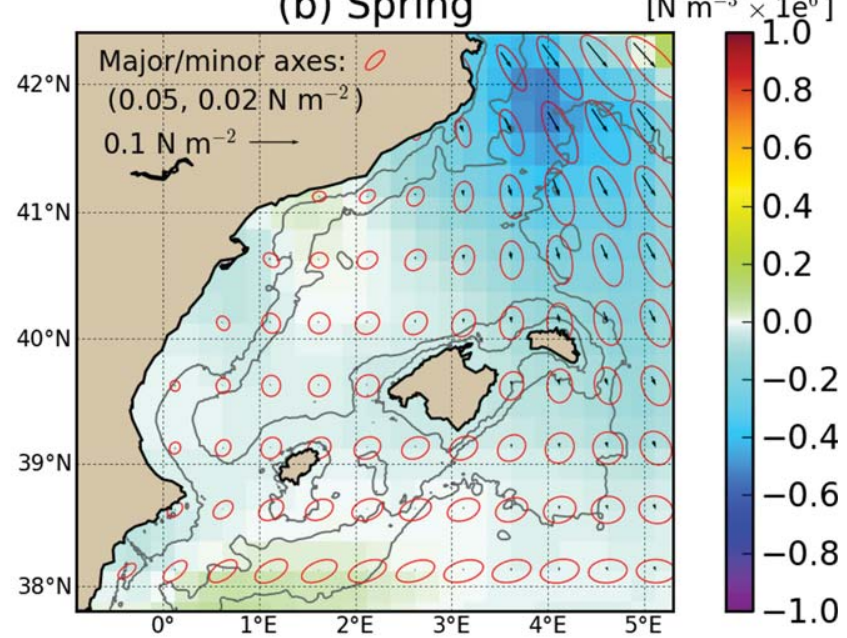

(d) Autumn

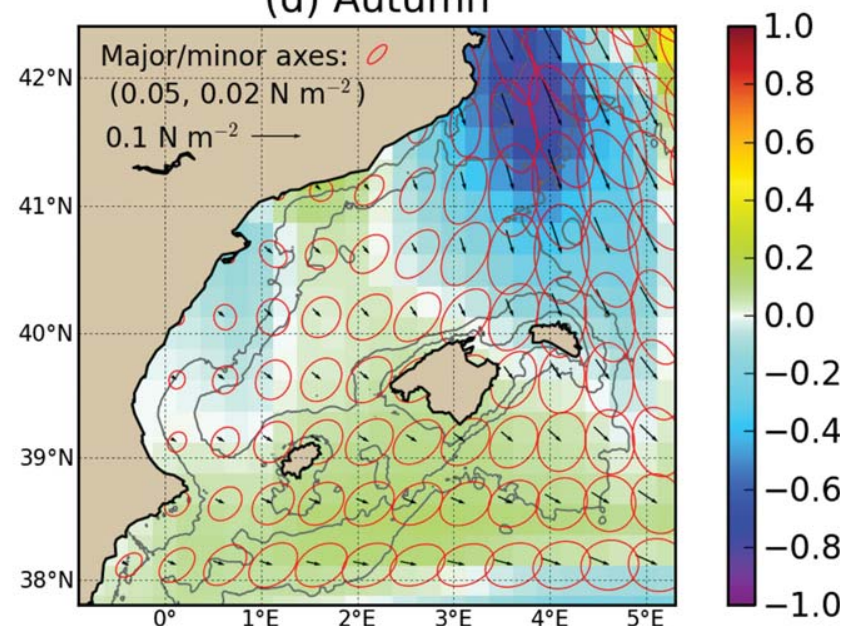

Figure 6. Mean seasonal wind stress vectors and variance ellipses, and the associated curl for the study period (19932010) over the Balearic Sea. Data derived from the CCMP $10 \mathrm{~m}$ wind speed database of Atlas et al.

[2011]. Isobaths are plotted in gray at 100, 1000, and $2500 \mathrm{~m}$.

character in the seasonal mean EKE (see also the mean SLA in Figure 2). Field observations over the Blanes canyon in spring 1983 [Masó and Tintoré, 1991] and summer and autumn 2003 [Flexas et al., 2008] have indicated cyclonic flow deflections that were attributed to water column stretching over the shelf break [see also Masó et al., 1990]. Flexas et al. [2008] reported both cyclonic and anticyclonic eddies of diameter close to the local Rossby deformation radius $(\sim 16 \mathrm{~km})$. Eddies of this size are too small to be resolved in the merged altimeter fields, but if they are persistent and numerous and are intersected by a satellite track then they may contribute to the elevated EKE seen near the canyon in Figure 5.

\subsection{Confidence Limits for SLA and EKE Estimates}

[38] Figure 7 shows confidence intervals for zonal profiles at $40.5^{\circ} \mathrm{N}$ of the seasonal mean SLA and EKE fields in Figures 2 and 5. Dark blue (red) lines show the SLA (EKE), while light blue (orange) lines indicate the respective $95 \%$ confidence intervals computed as described in section 3.1. (Note the large seasonal variability in the SLA which is obscured in Figure 2 by the removal of the spatial mean in each subplot.)

[39] SLA confidence intervals are marginally wider in winter and autumn, owing to the generally higher variance across the Balearic Sea during these seasons (not shown), and decrease in spring and summer. The uncertainties shown in Figure 7 (which are present across other parts of the study domain, not shown) are wide enough to suggest some caution in the interpretation of the SLA seasonal mean patterns presented in Figure 2. EKE confidence intervals are generally small near the coast (where mean EKE is also small), but widen in the interior Balearic Sea as mean EKE increases. Mean EKE seasonal mean patterns are most closely defined in spring. The generally small EKE uncertainties in Figure 7 (consistently the case across other parts of the study domain, not shown) indicate that the EKE seasonal mean patterns presented in Figure 5 are well defined.

[40] The largest regions of SLA and EKE uncertainty occur around peaks at $3.4^{\circ} \mathrm{E}$ in autumn (cf. Figures $2 \mathrm{~d}$ and 
Mean SLA and EKE $95 \%$ confidence limits at $40.5^{\circ} \mathrm{N}$
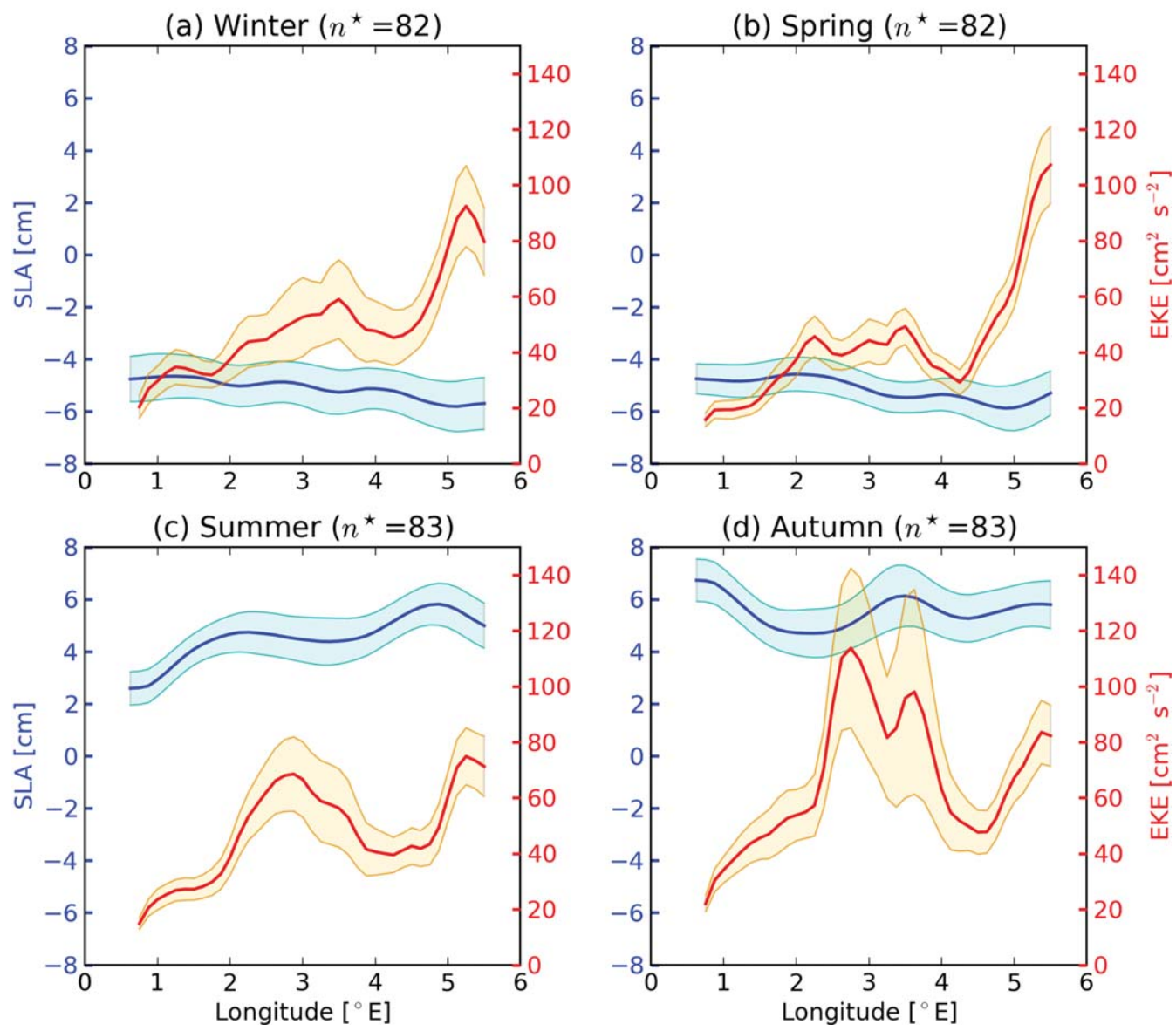

Figure 7. Zonal profiles of the seasonal mean and 95\% confidence intervals of the SLA (respectively, dark blue, light blue) and EKE (respectively, red, orange) at $40.5^{\circ} \mathrm{N} . n^{*}$ is the estimated number of independent SLA/

EKE observations used for the confidence interval estimations in section 3.1 .

5d). The season and location of this anticyclonic feature corresponds to the 1998 anticyclone described by Pascual et al. [2002] (see sections 5.3 and 5.4).

\section{Interannual Variability}

\subsection{Interannual Sea Level}

[41] Figures 8 and 9 show seasonal mean SLA for each year over the 1993-2010 measurement period, revealing significant interannual variability associated with the Balearic Sea.

\subsubsection{Winter}

[42] The salient features of the long-term winter SLA mean described in section 4.1.1 are elevated values over the shelf and slope of the Iberian margin, and cyclonic and anticyclonic SLA nodes north and northwest, respectively, of Ibiza and Mallorca (Figure 2a). Elevated shelf SLA is generally true in the interannual record, i.e., years 1996, 1997, 1998, 2001, 2003, 2004, 2007, 2009, and 2010. Within this selection, years 1996, 1998, 2009, and 2010 feature both the Mallorca anticyclonic SLA node and the Ibiza cyclonic SLA node. Direct examination of the 7 day SLA records indicates that the winter 2009 Mallorca anticyclone (Figure 9r1) is the same structure located in the basin interior during the previous season (i.e., autumn 2008,
Figure 9q4); this, however, is not the case for the 1998/ 1999 anticyclone (Figures 8f4 and 8g1; see sections 5.3 and 5.4). In 1996, 1997, and 1998, the wintertime SLAs are particularly high over the shelf south of the Ebre delta.

[43] Departures from the high long-term wintertime shelf SLA values are seen in years 1993, 1994, 1995, 1999, 2000, 2002, 2005, 2006, and 2008. The year 1993 has the lowest anomalies, with extrema $(\lessgtr-4 \mathrm{~cm})$ along the Catalan coast and extending into the Balearic Basin (Figure 8a1). Algerian eddy activity, generally low in winter in the northern Algerian Basin (e.g., Figure 5a), is at its highest ( $\gtrsim 6 \mathrm{~cm}$ ) over the wintertime record in 1993 (Figure 8a1). The similarly exceptional winter 1999 SLA pattern in Figure $8 \mathrm{~g} 1$ may be attributed to events starting in the previous summer (see Figures $8 \mathrm{f} 3$ and $8 \mathrm{f} 4$; see sections 5.3 and 5.4 ); it is noteworthy that the lowest wintertime SLA in the Algerian Basin occurs in this same year.

\subsubsection{Spring}

[44] A marked feature in the long-term spring SLA (Figure $2 \mathrm{~b}$ ) is an intense cyclonic SLA node at the Blanes canyon. Clear examples of cyclonic anomalies in the vicinity of the canyon are observed in the interannual record on six occasions, in 1993, 1995, 2000, 2003, 2008, and 2009 (Figures $8 \mathrm{a} 2,8 \mathrm{c} 2,912$, and 9q2), of which the 1995 and 2008 events have the greatest intensities. In 2008 an accompanying 


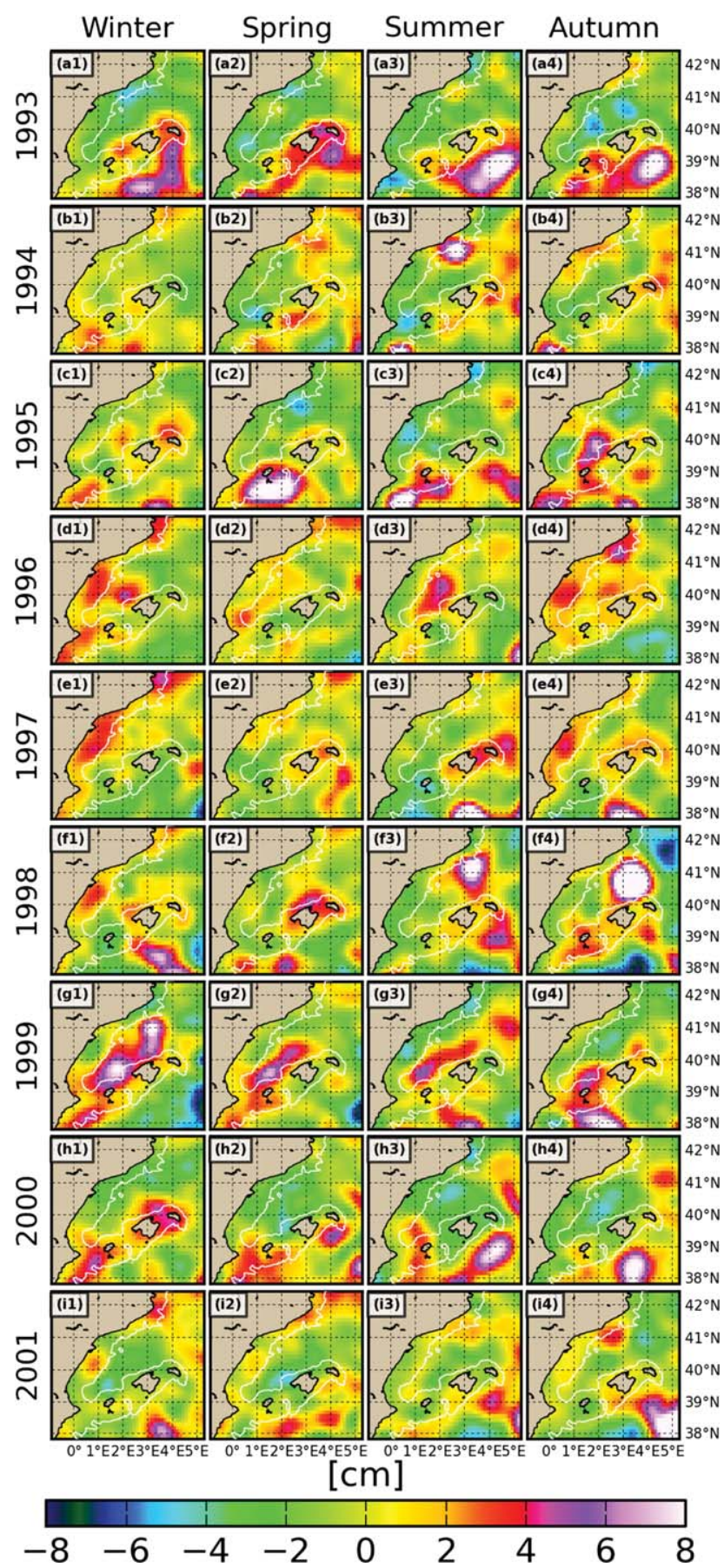

Figure 8. Seasonal mean SLA for the period 1993-2001. Isobaths are plotted in white at $1000 \mathrm{~m}$.

anticyclonic SLA node is observed to the southwest, which is sampled and described by Bouffard et al. [2010]. Recomputation of the long-term spring SLA omitting the years 1995 and 2008 (1993, 1995, 2003, and 2008) leads to a reduction by about $0.3(0.45) \mathrm{cm}$ in the magnitude of the cyclonic anomaly, and $0.18(0.37) \mathrm{cm}$ for the anticyclonic anomaly; the cyclonic anomaly remains as a coherent feature (figures not shown).

[45] Similarly to winter, the 1993 spring SLA pattern (Figure 8a2) is highly anomalous in comparison with other years, although it does not have the most extreme values.

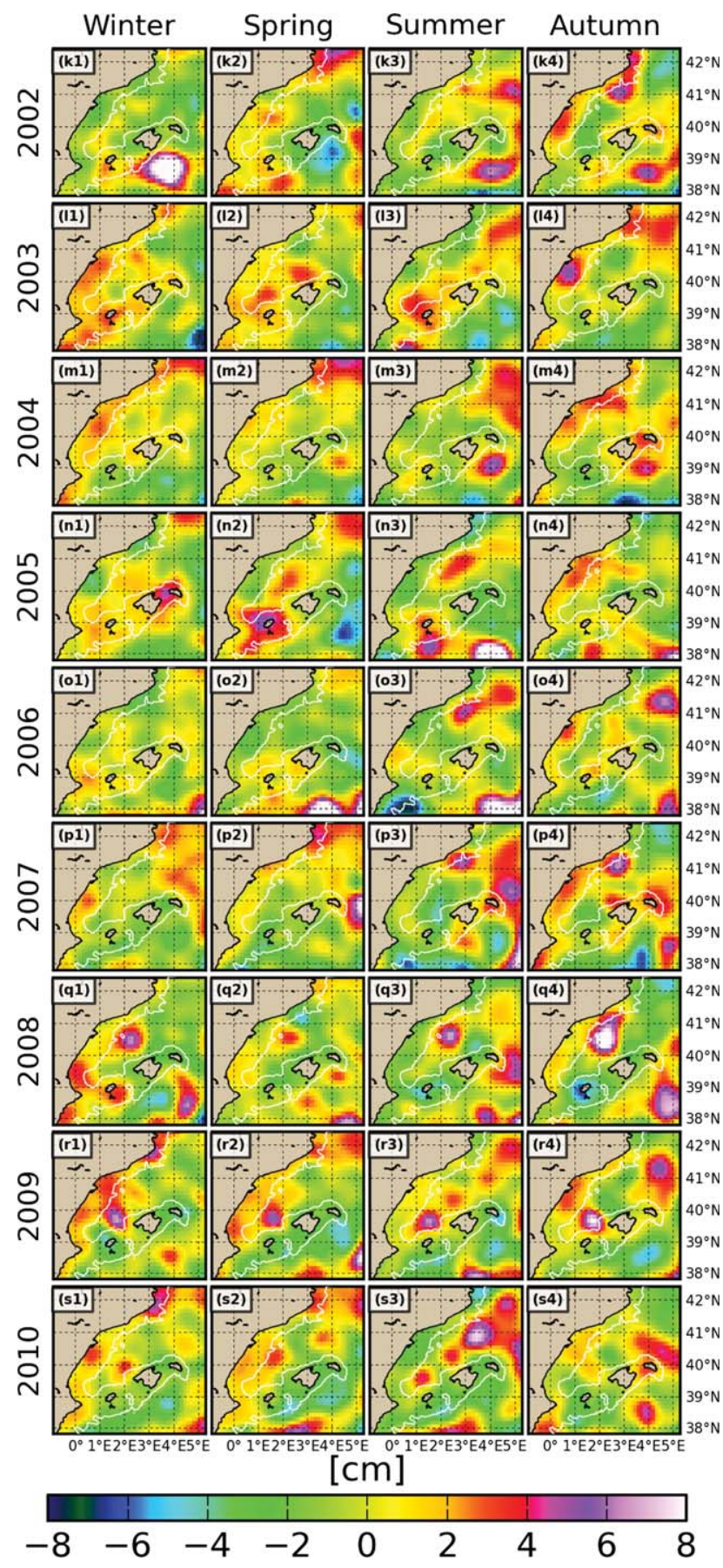

Figure 9. Seasonal mean SLA for the period 2002-2010. Isobaths are plotted in white at $1000 \mathrm{~m}$.

Instead, the highest SLAs (excluding those clearly associated with Algerian eddies, e.g., 2006) in the springtime record are found in 1995, where an extensive anticyclonic SLA with magnitude $\sim 9 \mathrm{~cm}$ lies along the shelf break south of Ibiza (Figure 8c2). (This anomaly is reminiscent of a positive anomaly in the RioMed MDT, which is assumed to be erroneous, e.g., Vidal-Vijande [2012]). Extensive patches of significantly low SLA are found southeast of Mallorca in 1998, 2002, 2005, 2009, 2010; these show up in the long-term mean (Figure 2b). The most striking anticyclonic anomaly within the Balearic Basin in 
the springtime record occurs in 1999; this is a vestige of the summer 1998 anticyclone (see section 5.3).

\subsubsection{Summer}

[46] The summer long-term mean current anomaly pattern tends to act counter to the winter pattern (section 4.1); hence, the SLA tends to be larger within the Balearic Basin than over the Iberian shelf and slope (Figure 2c). At least 11 years of the summer SLA record in Figures 8 and 9 conform to this general description; minimum shelf values are evident in 1993, 1994, 1995, 1999, 2002, 2003, 2004, 2005, 2006, 2008, and 2010. The lowest values $(\$ 4 \mathrm{~cm})$ are concentrated over the Valencian shelf just south of the Ebre delta (e.g., 1995, 1999, and 2010); these correspond to the long-term summer mean cyclonic SLA node shown at this location in Figure 2c.

[47] Summertime eddy-like mesoscale structures with high SLA values $(\gtrsim 6 \mathrm{~cm}$ ) within the Balearic Basin are seen in Figures 8 and 9 in 1994, 1998, 2008, and 2010. The 1998 anticyclone produced the largest anomalies in the Balearic Basin over the satellite record (Figure 8f3; see sections 5.3 and 5.4). Also reported in the description of the long-term summer SLA is an anticyclonic anomaly north of Ibiza. This feature is most intense in the summer fields in 2009 (Figure 9r3), but is also visible in 1999, 2003, and 2010.

\subsubsection{Autumn}

[48] The long-term autumn SLA featured maximum anomalies along the Iberian slope and shelf, and large anomalies across the Mallorca and Menorca channels and around the islands themselves. Low SLA values were found in the Ibiza channel, extending northeastward into the Balearic Basin. Minimum autumn SLA values are observed in 1993 (Figure 8a4), in the form of two large cyclonic recirculations in the interior Balearic Basin. An allyear all-season maximum $(\sim 30 \mathrm{~cm}$ in the weekly data) occurs in 1998 with the further development of the anticyclonic eddy first observed in the preceding summer season (cf. Figures $8 \mathrm{f3}$ and 8f4).

[49] In the interannual record, just 2 years, 1995 and 2009 (Figures 8c4 and 9r4), display deviations from this pattern. In autumn 1995, a large anticyclonic eddy occupies the Balearic Basin north of Ibiza and Mallorca. GVA vectors along the northern insular slope indicate a retarded mean $\mathrm{BC}$; this is contrary to the long-term autumn SLA (section 4.1 and Figure 2d) which shows an enhanced BC. In autumn 2009, a large anticyclonic eddy occupies the northern limit of the Mallorca channel.

\subsection{Water Mass Anomalies}

[50] Water mass anomalies are sources of low-frequency variability in the thermocline layer of the Balearic Sea. These anomalies are typically formed by short highfrequency events, such as cold snaps in winter over the GoL or rainstorms over the Ebre drainage basin, yet they may persist on timescales from months to years.

\subsubsection{Ibiza Channel}

[51] The formation and spreading of WIW has an impact on interannual variability of the mesoscale circulation at the Balearic channels (section 2). The mean spring/summer SLA fields in 1996 and 1997 (Figures 8d2, 8d3, 8e2, and 8e3) show, respectively, a pattern where WIW is absent and the NC flows unimpeded through the Ibiza channel, and a pattern where WIW blocks the channel and the NC is diverted toward the BC [cf., Pinot et al., 2002; Monserrat et al., 2008].

[52] To examine interannual variability of WIW formation, Monserrat et al. [2008] formulated an index (the IDEA index) based on time series of standardized air temperature anomalies $\left(T_{s}\right)$ in the GoL, defined as:

$$
T_{s}=\frac{T-\bar{T}}{\sqrt{\overline{(T-\bar{T})^{2}}}}
$$

where $T$ is a time series of daily air temperature averaged over the winter months (December to March) at $1000 \mathrm{mb}$ at $5^{\circ} \mathrm{E}, 42.5^{\circ} \mathrm{N}$ (a single point within the GoL) from NCEPNCAR; overbars indicate the full-term temporal mean. Figure 10a shows the IDEA index over the 1993-2010 study period: low values predict WIW presence $\left(\mathrm{WIW}_{T}\right)$ in the Ibiza channel, while its absence $\left(\mathrm{WIW}_{F}\right)$ is predicted by high values; an approximate band of uncertainty separates the two regions. Bold black semicircles correspond to in situ observations indicating WIW presence/absence according to Monserrat et al. [2008] and Vargas-Yáñez et al. [2012]. For the years where no observational data are available (1994, 2005-2009), the IDEA index in Figure 10a suggests that WIW was present, albeit with some uncertainty in 2007.

[53] The utility of the IDEA index as a skillful predictor of WIW formation in the absence of in situ observations has been affirmed by Jordi and Hameed [2009], who reported a significant binary correlation between the index and available WIW observations. Nevertheless, we caution that the nonobservation of WIW in the Ibiza channel in the high-IDEA index years (i.e., 1997, 1998, and 2001) does not necessarily preclude its generation in the GoL, or its presence in the channel, at those times. Jordi and Hameed [2009] also showed that the IDEA index is significantly correlated with fluctuations in the wintertime Icelandic low-pressure system over the North Atlantic, thus enabling the identification of an optimum synoptic environment over western Europe for WIW formation, namely northeasterly winds and very cold air temperatures.

[54] In Figures 11 and 12, following the ideas of Pinot et al. [2002], we use the IDEA index information from Figure 10a to investigate the impact of Ibiza channel WIW presence or absence on circulation through the Balearic channels. PDFs of the seasonal GVAs through the Ibiza and Mallorca channels are shown that are similar to those presented in Figures 3 and 4 in section 4.2, but here the time series are filtered according to WIW presence as defined by the IDEA index. A consequence of the filtering is a considerably reduced sample size for $\mathrm{WIW}_{F}$ (see $n$ in Table 2), as we can select only four years (1997, 1998, 2001, and 2007); note that uncertain years in Figure 10a are defined as being representative of WIW $_{F}$ (unless in situ observations show otherwise). The results show that in both channels the basic seasonal character, i.e., greater probability for stronger (lower) GVA in winter (summer), persists. However, in the Ibiza channel, there is a marked shift between stronger northward (southward) GVA with the presence (absence) of WIW (Figure 11). This effect is strongest in winter, but is present all years. In the Mallorca 

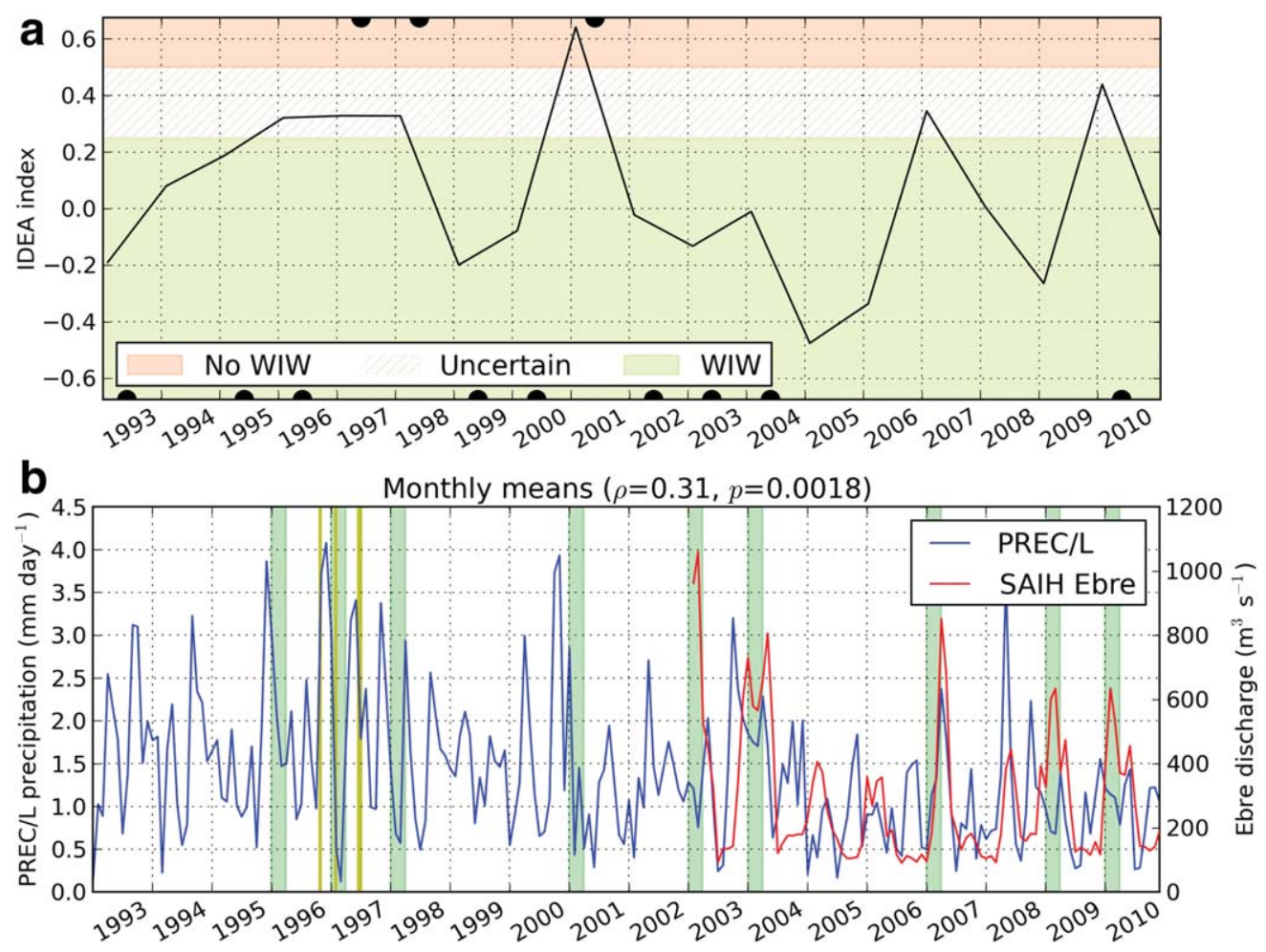

Figure 10. (a) The IDEA wintertime (December to March) index from 1993 to 2010. The index is calculated using daily NCEP air temperature data over the Gulf of Lions for the period 1948-2012. Shaded areas indicate relative likelihood of WIW formation. Filled semicircles mark in situ observational evidence of WIW presence/absence in the Ibiza channel from Monserrat et al. [2008] and Vargas-Yáñez et al. [2012]; between 2005 and 2011 the index is currently unsupported by in situ observations. (b) Time series of monthly mean Ebre river discharges at Tortosa near the Ebre delta from SAIH (begins 2003), and monthly mean SLA over the Ebre shelf. Winters with large SLA over the Ebre shelf are shaded in green. The averaging period of the mean Ebre discharge corresponding to the winter 1997 FANS2 survey [Salat et al., 2002] is shaded in yellow.

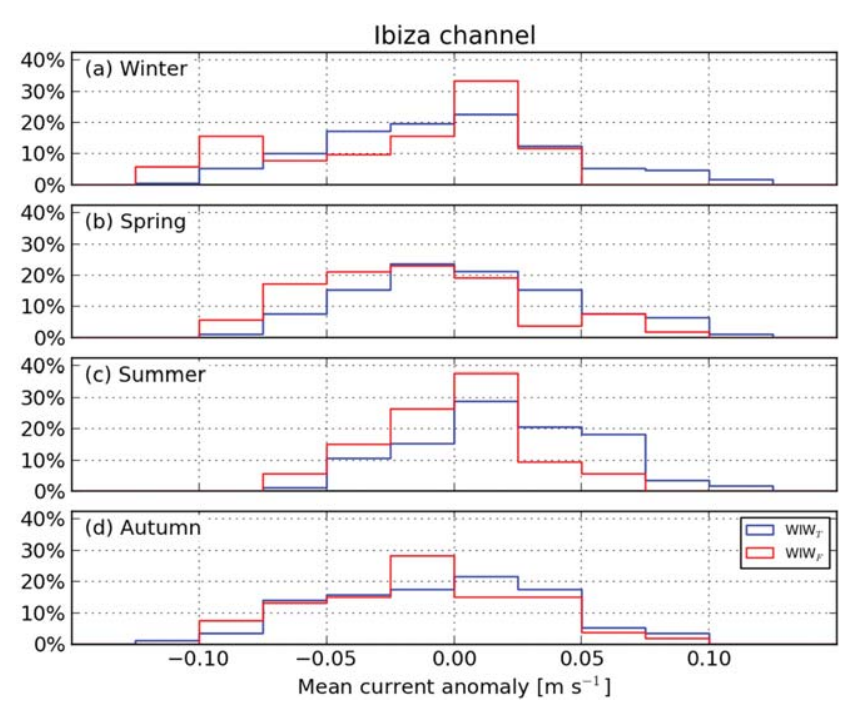

Figure 11. Seasonal PDFs of meridional surface GVA through the Ibiza channel $\left(\mathrm{GVA}_{\perp I C}\right)$. Two time ranges are sampled that correspond to years when Western Intermediate Water is present $\left(\mathrm{WIW}_{T}\right)$ or absent $\left(\mathrm{WIW}_{F}\right)$ in the channel (see section 5.2.1). See $n$ in Table 2 for sample sizes.

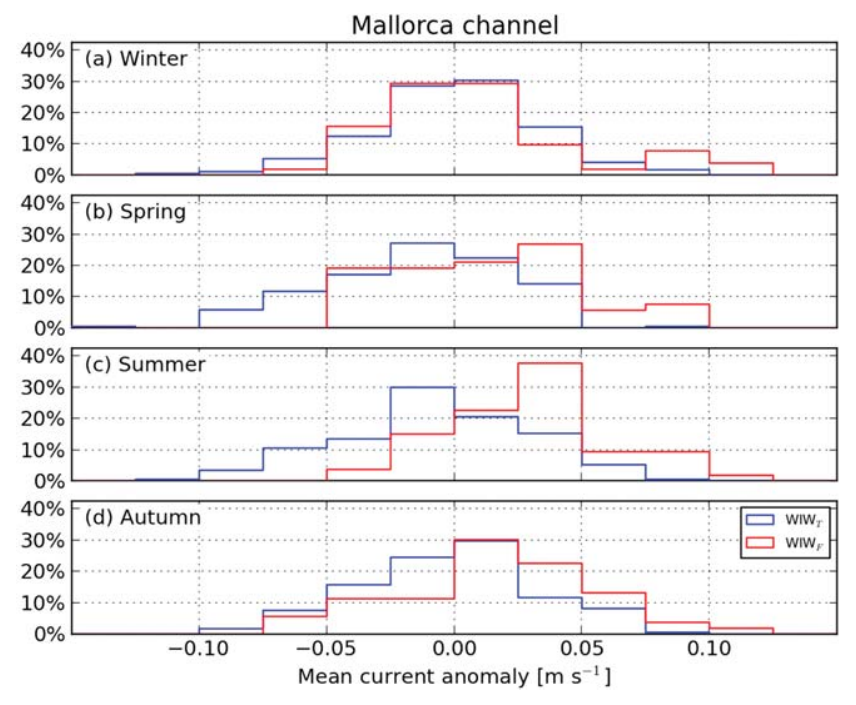

Figure 12. Seasonal PDFs of meridional surface GVA through the Mallorca channel $\left(\mathrm{GVA}_{\perp M C}\right)$. Two time ranges are sampled that correspond to years when Western Intermediate Water is present $\left(\mathrm{WIW}_{T}\right)$ or absent $\left(\mathrm{WIW}_{F}\right)$ in the Ibiza channel (see section 5.2.1). See $n$ in Table 2 for sample sizes. 
Table 2. The 1993-2010 Seasonal Means of Flow Anomalies Through the Ibiza Channel (GVA $\perp I C$, Shown in Figure 11) and the Mallorca Channel $\left(G_{\perp M C}\right.$, Shown in Figure 12) in Years Where Western Intermediate Water Is Present $\left(W_{I}\right)$ and $A_{b s e n t}\left(W_{I} W_{F}\right)^{a}$

\begin{tabular}{|c|c|c|c|c|c|c|c|c|}
\hline & Winter & Spring & Summer & Autumn & Winter & Spring & Summer & Autumn \\
\hline & \multicolumn{4}{|c|}{ Ibiza Channel } & \multicolumn{4}{|c|}{ Mallorca Channel } \\
\hline \multicolumn{9}{|l|}{$\mathrm{WIW}_{T}$} \\
\hline Mean & -0.4 & 0.5 & 2.0 & -0.6 & 0 & -1.4 & -0.7 & -0.2 \\
\hline Mean north & 3.4 & 3.7 & 3.7 & 3.1 & 2.4 & 2.4 & 2.7 & 2.6 \\
\hline Mean south & 3.7 & 2.8 & 2.4 & 4.0 & 2.6 & 3.6 & 3.2 & 3.0 \\
\hline$n$ & 168 & 169 & 170 & 171 & 168 & 169 & 170 & 171 \\
\hline \multicolumn{9}{|l|}{$\mathrm{WIW}_{F}$} \\
\hline Mean & -2.2 & -1.6 & 0 & 1.3 & 0.9 & 1.3 & 3.1 & 1.8 \\
\hline Mean north & 1.8 & 2.9 & 2.3 & 3.2 & 3.6 & 3.7 & 4.1 & 3.6 \\
\hline Mean south & 5.5 & 3.8 & 2.5 & 3.8 & 2.1 & 2.5 & 3.2 & 2.6 \\
\hline$n$ & 51 & 52 & 53 & 53 & 51 & 52 & 53 & 53 \\
\hline
\end{tabular}

${ }^{\text {a Subscript }}{ }_{T}\left({ }_{F}\right)$ denotes True (False). $n$ denotes the respective sample sizes. Units are given in $\mathrm{cm} \mathrm{s}^{-1}$.

channel, the pattern is reversed, with a tendency for more northward (southward) flows with the absence (presence) of WIW (Figure 12). Table 2 provides a summary of these results. The results are in good agreement with the observations of Pinot et al. [2002, see Figure 19].

\subsubsection{Ebre Shelf}

[55] The locations of the cyclonic and anticyclonic SLA nodes over the Ebre shelf identified in summer and autumn in Figures $2 \mathrm{c}$ and $2 \mathrm{~d}$ suggest a strong link to freshwater input from the Ebre river. Cool freshwaters associated with the plume are readily observed in satellite SST [e.g., López García et al., 1994] and hydrographic fields [Font et al., 1990; Salat et al., 2002]. The strong negative SLA gradient across the shelf and slope that is associated with the autumn anticyclonic anomaly and that accelerates the flow beyond its annual mean values coincides with rapid Ebre discharge increases that are characteristic of the autumn season [e.g., Lloret et al., 2004]. Font et al. [1990] reported anticyclonic circulation over the shelf in autumn 1984 and concluded that buoyancy input from the Ebre plume plays a significant role in defining the circulation along the Ebre shelf.

[56] In section 5.1.1, it was noted that especially high SLA values over the shelf south of the Ebre river delta were observed in several winters. For example, in winter 1997 where the SLA observations (Figure 8e1) coincide with in situ observations carried out over the Ebre shelf during February 1997, the mean Ebre discharge was fivefold its $\sim 400 \mathrm{~m}^{3} \mathrm{~s}^{-1}$ annual mean value (the FANS2 survey, Salat et al. [2002]). A large freshwater anomaly extended over a large area of the shelf offshore of the river mouth, with a volume estimate predicting an equivalent height of $28 \mathrm{~cm}$. The influence of this event is reflected in the 1997 winter SLA in Figure 8e1, where the NC is intensified over the slope and partially deflected eastward [e.g., Pinot et al., 2002]. A modeling study by Xing and Davies [2002a] has highlighted the role of local winds on the offshore spreading of the Ebre plume. Under mistral conditions, characterized by offshore-directed winds at the Ebre [García, 1982], their numerical results presented a strong anticyclonic surface gyre over the shelf, such as is seen in Figure 8e1. Examination of the CCMP wind data (not shown) indicates that winds over the Ebre shelf were generally light before and during FANS2, although a brief
Mistral event (wind speed $>10 \mathrm{~m} \mathrm{~s}^{-1}$ ) did occur immediately after the cruise (between 15 and 17 February 1997).

[57] To examine the relationship between Ebre river discharges and SLA over the Ebre shelf, we plot in Figure 10b a time series of monthly mean SAIH Ebre discharges and compare with monthly mean SLA averaged within a box region $\left(40.1^{\circ}-40.9^{\circ} \mathrm{N}, 0.4^{\circ}-1.1^{\circ} \mathrm{E}\right)$ located over the shelf. The SAIH data are only available from 2003 onward. Precipitation over the Iberian peninsula is modulated by the North Atlantic Oscillation and is highly seasonal, peak rainfalls occurring mainly in winter [Struglia et al., 2004; Lorenzo-Lacruz et al., 2012]. Winters with mean SLA >0 $\mathrm{m}$ are highlighted in green in Figure 10b, and the averaging period of the mean Ebre discharge corresponding to the FANS2 cruise is shown in yellow. In all of the highlighted winters, bar that of 2008, there is coincidence between periods of high discharge and high SLA over the Ebre shelf. This is in agreement with the winter 1997 FANS2 results of Salat et al. [2002].

[58] An example of a converse situation to that of FANS2, where Ebre discharges are below average and minimum SLA values are seen over the Ebre shelf, occurred in winter 2005 (Figures 10b and 9n1). This was an exceptionally severe winter with large heat losses over the GoL associated with successive northerly storms, and anomalously low Rhone discharges [López-Jurado et al., 2005; Font et al., 2007; Ulses et al., 2008].

[59] To further assess the relationship between the SLA/ Ebre outflow time series data sets in Figure 10b, we first tested the Ebre data for normality using the Shapiro-Wilks test. Finding a nonnormal distribution, a Spearman rank correlation coefficient $(\rho)$ was used as a measure of variability between the data sets. Assuming the data to be uncorrelated $\left(H_{0}\right)$, we find $\rho=0.32(p<0.01)$. The Spearman analysis was also performed on subsets of the data selecting only winter months, returning $\rho=0.56(p<0.01)$. Details of these statistics are provided in Table 3 . The significant positive $\rho$ values support an association between river outflow and elevated SLA over the Ebre shelf, especially in winter.

[60] Similar relationships can be expected near other river mouths. For example, a patch of elevated SLA seen over the shelf south of Cap de Creus in spring 2007 (Figure 9p2), 
Table 3. Spearman Rank Correlation Coefficients $(\rho)$ Between Monthly Mean Ebre River Discharges and Ebre Shelf SLA Between 2003 and $2010^{\mathrm{a}}$

\begin{tabular}{lcccc}
\hline & $\mathrm{n}$ & $R^{2}$ & $\rho$ & $\mathrm{p}$ \\
\hline Monthly means & 97 & 0.16 & 0.32 & 0.001 \\
Winter monthly means & 24 & 0.22 & 0.56 & 0.004
\end{tabular}

${ }^{\mathrm{a}}$ The first row correlates all months, while for the second row, only winter months (JFM) are considered.

appears to coincide with April peak river discharges at Cap de Creus and Palamos reported by Ribó et al. [2011].

\subsection{Eddies}

[61] Figures 8 and 9 demonstrate the range of scales of variability of eddy-like mesoscale structures that populate the Balearic Sea, many lasting for several months. The prime example is the 1998 anticyclone in the center of the basin in Figures 8f3-8g1. This eddy persisted for 7 months between September 1998 and March 1999 with a diameter of up to $100 \mathrm{~km}$ [Larnicol et al., 2002; Pascual et al., 2002]. The structure strongly modified the Balearic Sea circulation, occupying almost the full meridional extent of the eastern basin in autumn 1998. Birol et al. [2010] reported anomalous (northeastward) current meter readings in winter 1999 from as far away as the slope near the Ebre delta (cf. Figure 8g1).

[62] The second most intense anticyclone in the MSLA record appeared approximately $100 \mathrm{~km}$ to the north of Mallorca in summer 2010 (Figure 9s3). Monthly mean interannual SLA (not shown) reveals that the amplitude of this anomaly was significant although its lifetime was short, lasting just 3 months in comparison with the 1998 eddy that persisted for about 5 months.

[63] A similar eddy to the 1998 anticyclone appeared exactly a decade later in 2008 (Figures 9q2-9q4). Less intense than the 1998 event and located $\sim 1^{\circ}$ further west, the 2008 eddy reached maturity in autumn 2008 and by winter 2009 had migrated toward the Mallorca channel. Bouffard et al. [2010] observed the anticyclone in April 2008 using both altimetry and glider data from repeated missions between the Iberian Peninsula and Mallorca. Clear signals associated with the eddy (and also the NC and $\mathrm{BC}$ ) were found in the glider data; concurrent SST maps revealed a strong Balearic front, but a much weaker Catalan front. Details of the $\mathrm{NC}$ and $\mathrm{BC}$ are missing in Figure $9 q 2$ (this is partially because of the permanent nature of these features, which reduces their prominence in the anomaly fields), but the along-slope SLA gradient is indicative of the strong Balearic front north of Mallorca. Referring to the eddy as "ASTERIX", Bouffard et al. [2012] used gliders, altimetry, and a numerical model to argue that it originated as a result of salinity gradients associated with the Balearic front. The persistence of the 2008 eddy is remarkable: it first appears south of Barcelona in winter 2008 (Figure 9q1) and can then be tracked in weekly SLA maps (not shown) through to May 2009 when it lies northwest of Mallorca. During this period, the eddy undergoes several changes in size and intensity and interacts with nearby mesoscale structures. The seasonal SLA maps in Figures 9r2-9s1 suggest that the eddy persists even longer, until winter 2010, but examination of individual weekly maps reveals an interruption, and it appears that a new eddy is spawned northwest of Mallorca in late May 2009; the intense frontal region associated with this new eddy (Figure 9r4) is investigated by Balbin et al. [2012].

[64] Another large anticyclone occupying the center of the Balearic Basin is seen in spring and summer 2005 (Figures 9n2 and 9n3). Schroeder et al. [2008] sampled in situ the eastern periphery of this eddy in April 2005, reporting associated absolute geostrophic velocities near the surface of $\sim 10 \mathrm{~cm} \mathrm{~s}^{-1}$ with a signal extending down to about 100 $\mathrm{m}$ depth.

[65] Numerous smaller mesoscale anticyclonic eddies along the Catalan coast are visible in Figures 8 and 9. Many of these so-called Catalan eddies have been described in the literature: For example, the anticyclone near Blanes in autumn 2001 in Figure 8i1 was sampled in situ by Rubio et al. [2005] and later modeled by Rubio et al. [2009]. The eddy had a diameter of $\sim 45 \mathrm{~km}$, azimuthal velocities of about $50 \mathrm{~cm} \mathrm{~s}^{-1}$, and was detectable down to $\sim 100 \mathrm{~m}$ depth. The model simulations indicated that the eddy was generated just south of Cap de Creus in response to flow separation near the cape brought on by current intensification that was linked, in turn, to a Tramuntana event in the GoL. Another example is the autumn 2002 anticyclonic eddy near to Blanes (Figure 9k4) that was observed in SST and modeled by Onken et al. [2008]. Finally, a large anticyclone appeared at the Blanes canyon in summer and autumn of 2007 (Figures 9p3 and 9p4). This eddy appears to precede the winter 2008 anticyclone described earlier in this section, but examination of monthly SLA maps (not shown) indicates the two are not related. The eddy presented a strong SST anomaly in summer/autumn 2007, and was shown to have originated under summertime wind stress (Tramuntana) forcing in the GoL [Garreau et al., 2011].

[66] It is notable that all of the abovementioned eddies are anticyclonic. The anticyclonic circulation of the western GoL has been cited as a potential source region for (sub)mesoscale anticyclonic eddies [e.g., Estournel et al., 2003; Hu et al., 2009]. These may interact with the NC and go on to become Catalan eddies through mechanisms such as those proposed in the numerical studies of Garreau et al. [2011] and Hu et al. [2011]. We have not seen evidence for persistent cyclonic eddies in our results nor in the literature of the Balearic Sea, save for the fixed cyclonic circulations located over the continental canyons.

\subsection{Eddy Impact on Seasonal Means}

\subsubsection{Impact on SLA}

[67] The observed amplitudes of the anticyclones discussed in section 5.3 above begs the question of their potential impact on the seasonal mean SLA in Figure 2 (section 4.1). Figure 13 shows summer and autumn SLA means computed with the omission of one or more years that correspond to the presence of important anticyclones within the Balearic Basin; these are 1998, 2008, and 2010 (section 5.3).

[68] In summer (Figure 13a), we see that removing the major 1998 anticyclone slightly reduces the intensity of the SLA just south of the Blanes canyon. The additional removal of the second most intense summertime anomaly 

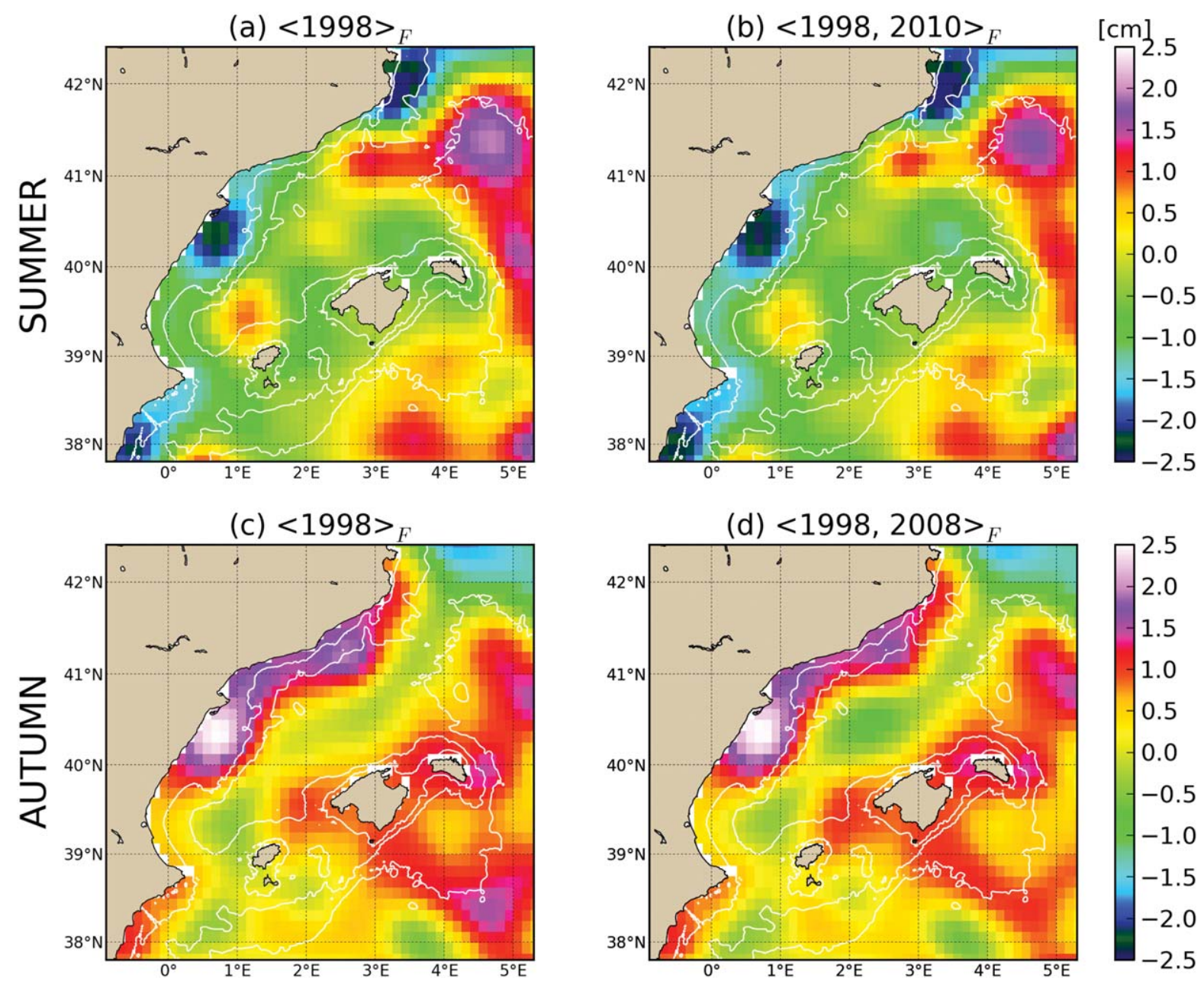

Figure 13. (top) Summer mean SLA computed with the omission of years (a) 1998 and (b) 1998 and 2010; see Figure 2c for the full 1993-2010 mean. (bottom) Autumn mean SLA computed with the omission of years (c) 1998 and (d) 1998 and 2008; see Figure 2d for the full 1993-2010 mean. Isobaths are plotted in white at 100,1000 , and $2500 \mathrm{~m}$.

(2010) in Figure 13b leads to a weakening of the connection between the Blanes canyon anticyclone and the PCG to the east, both of which become independent nodes with nominally closed circulation anomalies. Nevertheless, despite these small differences, the figures reveal that the characteristic summer circulation defined in Figure $2 \mathrm{c}$ remains the dominant pattern.

[69] In contrast, the removal of the 1998 anticyclone in autumn has a more significant impact than in summer. In Figure $13 \mathrm{c}$, the anticyclone situated north of the Menorca channel that is present in the 1993-2010 autumn SLA of Figure $2 \mathrm{~d}$ is totally absent. As a consequence, the NC and BC more closely follow the classic schematic patterns associated with these currents, as depicted in Figure 1. The additional removal of the 2008 SLA introduces a weak cyclonic anomaly at the center of the basin, but does not significantly change the overall pattern any further.

\subsubsection{Impact on EKE}

[70] Multiyear averages of EKE in the Mediterranean can be susceptible to bias from the occurrence of intermittent mesoscale events, especially in regions with relatively low variability such as the Balearic Sea, where Pujol and
Larnicol [2005] explain the impact of the 1998 anticyclone (see section 5.3; Figures 8f3-8g1) on mean EKE. This anomaly does indeed contribute to the peak autumn EKE signal in the Balearic Sea in Figure 5d. However, a recomputation of the autumn EKE without the year 1998 (not shown) still returns an elevated EKE pattern in the center of the basin, albeit with a reduction in intensity of $\sim 25 \%$ (but see section 5.4.1 for the impact on SLA), further confirming that elevated autumn EKE is characteristic of the seasonal cycle.

\section{Conclusions}

[71] In this paper, we have used a long-term altimeter SLA data set to study variability at a range of scales in the Balearic Sea. We find that the magnitude of the mean geostrophic current anomaly that corresponds to the $\mathrm{NC}$ in the region of the Ebre slope is highest in autumn rather than winter. A subbasin scale gyre to the south of the GoL is identified, which we name the PCG; the gyre is prominent in winter and summer. EKE is found to be highest across the Balearic Sea in autumn and weakest in spring. 
[72] We demonstrate the viability of altimeter data for studying variability across the Balearic channels. Seasonal PDFs of GVA across the Ibiza channel indicate that the mean NC anomaly here is strongest in winter. A further set of PDFs, plotted for years with and without the predicted presence of Western Intermediate Water in the channel, is consistent with the theory that this water mass acts to block the channel. This is the first study to exploit altimeter data for a description of variability within the straits.

[73] Seasonal SLA means corresponding to individual years over the study period allow the identification of mesoscale anticyclonic eddies within the Balearic Sea. Several of these eddies have been the focus of previous studies that have utilized remote-sensing data, in situ observations, and/or numerical model outputs. The interannual seasonal SLA means also reveal a positive relationship between Ebre river discharge and SLA over the nearby Ebre shelf, especially in winter.

[74] Our results demonstrate the value of a long-term (multidecadal) merged altimeter data set for studies of oceanic mesoscale processes and variability. Given the recent demise of Envisat [Brumfiel, 2012] and changes to the Jason-1 orbit, it is vital that future satellite missions continue to accommodate the need for merging of altimeter data in support of mesoscale ocean observations. At the same time, continued efforts to improve satellite altimeter data resolution through, for example, the deployment of advanced instruments such as SWOT [Fu et al., 2010], the development of new mapping techniques [e.g., Dussurget et al., 2011; Escudier et al., 2013], and multisensor complementary approaches that combine other remotely sensed products (e.g., SST, ocean color) and/or in situ data from gliders and drifters [e.g., Pascual et al., 2010] with the satellite SLA, are imperative. In order to better understand the role of mesoscale processes in the dynamics of the Balearic Sea, integrated approaches that utilize observational data in conjunction with numerical model outputs will also be necessary.

[75] Acknowledgments. Evan Mason is supported by a Spanish government JAE-Doc grant (CSIC), cofinanced by FSE. This work has been partially funded by the project MyOcean-2 EU FP7. The altimeter products were produced by Ssalto/Duacs and distributed by AVISO, with support from Cnes (http://www.aviso.oceanobs.com/duacs/). NCEP Reanalysis data were provided by the NOAA/OAR/ESRL PSD, Boulder, Colorado, from their Web site at http://www.esrl.noaa.gov/psd/. Monthly mean Ebre outflow data at Tortosa (station A027) were provided by the Sistema Automático de Información Hidrológica de la Cuenca Hidrográfica del Ebro from their Web site at http://195.55.247.237/saihebro/index. php?url=/principal. Lastly, we extend our thanks to three anonymous reviewers for valuable comments and corrections that significantly improved the manuscript.

\section{References}

Álvarez, A., J. Tintoré, G. Holloway, M. Eby, and J.-M. Beckers (1994), Effect of topographic stress on circulation in the western Mediterranean, J. Geophys. Res., 99(C8), 16,053-16,064, doi:10.1029/94JC00811.

Amitai, Y., Y. Lehahn, A. Lazar, and E. Heifetz (2010), Surface circulation of the eastern Mediterranean Levantine basin: Insights from analyzing 14 years of satellite altimetry data, J. Geophys. Res., 115, C10058, doi:10.1029/2010JC006147.

Arbic, B. K., R. B. Scott, D. B. Chelton, J. G. Richman, and J. F. Shriver (2012), Effects of stencil width on surface ocean geostrophic velocity and vorticity estimation from gridded satellite altimeter data, J. Geophys. Res., 117, C03029, doi:10.1029/2011JC007367.
Atlas, R., R. N. Hoffman, J. Ardizzone, S. Mark Leidner, J. C. Jusem, D. K. Smith, and D. Gombos (2011), A cross-calibrated, multiplatform ocean surface wind velocity product for meteorological and oceanographic applications, Bull. Am. Meteorol. Soc., 92(2), 157-174, doi:10.1175/ 2010BAMS2946.1.

AVISO, Archiving, Validation and Interpretation of Satellite Oceanographic data (2012), Ssalto/Duacs User Handbook: (M)SLA and (M)ADT Near-Real Time and Delayed Time Products, 2.9 ed., SALPMU-P-EA-21065-CLS. [Available online at http://www.aviso.oceanobs.com/en/data/tools/aviso-user-handbooks.html.]

Balbín, R., M. M. Flexas, J. L. López-Jurado, M. Peña, and F. Alemany (2012), Vertical velocities and biological consequences at a front detected at the Balearic Sea, Cont. Shelf Res., 47, 28-41, doi:10.1016/ j.csr.2012.06.008.

Bergamasco, A., and P. Malanotte-Rizzoli (2011), The circulation of the Mediterranean Sea: A historical review of experimental investigations, $A d v$. Oceanogr. Limnol., 1(1), 11-28, doi:10.1080/19475721.2010.491656.

Birol, F., M. Cancet, and C. Estournel (2010), Aspects of the seasonal variability of the Northern Current (NW Mediterranean Sea) observed by altimetry, J. Mar. Syst., 81(4), 297-311, doi:10.1016/j.jmarsys.2010.01.005.

Bouffard, J., A. Pascual, S. Ruiz, Y. Faugère, and J. Tintoré (2010), Coastal and mesoscale dynamics characterization using altimetry and gliders: A case study in the Balearic Sea, J. Geophys. Res., 115, C10029, doi:10.1029/2009JC006087.

Bouffard, J., L. Renault, S. Ruiz, A. Pascual, C. Dufau, and J. Tintoré (2012), Sub-surface small-scale eddy dynamics from multi-sensor observations and modeling, Prog. Oceanogr., 106, 62-79, doi:10.1016/ j.pocean.2012.06.007.

Brumfiel, G. (2012), Nature, 484, 423-424, doi:10.1038/484423a.

Canals, M., P. Puig, X. Durrieu de Madron,S. Heussner, A. Palanques, and J. Fabrés (2006), Flushing submarine canyons, Nature, 444, 354-357, doi:10.1038/nature05271.

Canals, M., R. Danovaro, S. Heussner, V. Lykousis, P. Puig, F. Trincardi, A. Calafat, X. Durrieu de Madron, A. Palanques, and A. Sànchez-Vidal (2009), Cascades in Mediterranean submarine grand canyons, Oceanography, 22(1), 26-43, doi:10.5670/oceanog.2009.03.

Capet, X. J., E. J. Campos, and A. M. Paiva (2008a), Submesoscale activity over the Argentinian shelf, Geophys. Res. Lett., 35, L15605, doi: 10.1029/2008GL034736,2008.

Capet, X. J., J. C. McWilliams, M. J. Molemaker, and A. F. Shchepetkin (2008b), Mesoscale to submesoscale transition in the California current system. Part II: Frontal processes, J. Phys. Oceanogr., 38(1), 44-64, doi: $10.1175 / 2007$ JPO3672.1.

Castellón, A., J. Font, and E. García (1990), The Liguro-Provençal-Catalan current (NW Mediterranean) observed by Doppler profiling in the Balearic Sea, Sci. Mar., 54(3), 269-276.

Chelton, D. B., M. G. Schlax, M. H. Freilich, and R. F. Milliff (2004), Satellite measurements reveal persistent small-scale features in ocean winds, Science, 303(5660), 978-983, doi:10.1126/science.1091901.

Chronis, T., V. Papadopoulos, and E. I. Nikolopoulos (2011), QuickSCAT observations of extreme wind events over the Mediterranean and Black Seas during 2000-2008, Int. J. Climatol., 31(14), 2068-2077, doi: $10.1002 /$ joc. 2213 .

Colas, F., J. C. McWilliams, X. J. Capet, and J. Kurian (2012), Heat balance and eddies in the Peru-Chile current system, Clim. Dyn., 39(1-2), 509529, doi: 10.1007/s00382-011-1170-6.

Dai, A., and K. E. Trenberth (2002), Estimates of freshwater discharge from continents: Latitudinal and seasonal variations, J. Hydrometeorol., 3(6), 660-687, doi:10.1175/1525-7541(2002)003<0660:EOFDFC $>2.0 . C O ; 2$.

Dorman, C. E., R. C. Beardsley, and R. Limeburner (1995), Winds in the Strait of Gibraltar, Q. J. R. Meteorol. Soc., 121(528), 1903-1921, doi:10.1002/qj.49712152807.

D’Ortenzio, F., D. Iudicone, C. de Boyer Montégut, P. Testor, D. Antoine, S. Marullo, R. Santoleri, and G. Madec (2005), Seasonal variability of the mixed layer depth in the Mediterranean Sea as derived from in situ profiles, Geophys. Res. Lett., 32, L12605, doi:10.1029/2005GL022463.

Dussurget, R., F. Birol, R. Morrow, and P. De Mey (2011), Fine resolution altimetry data for a regional application in the Bay of Biscay, Mar. Geod., 34(3-4), 447-476, doi:10.1080/01490419.2011.584835.

Escudier, R., J. Bouffard, A. Pascual, P.-M. Poulain, and M.-I. Pujol (2013), Improvement of coastal and mesoscale observation from space: Application to the Northwestern Mediterranean Sea, Geophys. Res. Lett., 40, doi:10.1002/grl.50324.

Espino, M., A. Sánchez-Arcilla, and M. A. García (1998), Wind-induced mesoscale circulation off the Ebro delta, NW Mediterranean: A 
numerical study, J. Mar. Syst., 16(3-4), 235-251, doi:10.1016/S09247963(97)00110-3

Estournel, C., X. Durrieu de Madron, P. Marsaleix, F. Auclair, C. DufauJulliand, and R. Vehil (2003), Observation and modeling of the winter coastal oceanic circulation in the Gulf of Lion under wind conditions influenced by the continental orography (FETCH experiment), J. Geophys. Res., 108, 8059, doi:10.1029/2001JC000825.

Flexas, M. M., X. Durrieu de Madron, M. A. García, M. Canals, and P. A Arnau (2002), Flow variability in the Gulf of Lions during the MATER HFF experiment (March-May 1997), J. Mar. Syst., 33-34, 197-214, doi:10.1016/S0924-7963(02)00059-3.

Flexas, M. M., D. L. Boyer, M. Espino, J. Puigdefâbregas, A. Rubio, and J. B. Company (2008), Circulation over a submarine canyon in the NW Mediterranean, J. Geophys. Res., 113, C12002, doi:10.1029/ 2006JC003998..

Font, J. (1990), A comparison of seasonal winds with currents on the continental slope of the Catalan Sea (Northwestern Mediterranean), J. Geophys. Res., 95(C2), 1537-1545, doi:10.1029/JC095iC02p01537.

Font, J., J. Salat, and J. Tintoré (1988), Permanent features of the circulation in the Catalan Sea, in Pelagic Mediterranean Oceanography, vol. 9, edited by H. J. Minas and P. Nival, pp. 51-57, Oceanol. Acta, GauthierVillars, Montrouge, France.

Font, J., J. Salat, and J. Agustí (1990), Marine circulation along the Ebro continental margin, Mar. Geol., 95(3-4), 165-177, doi:10.1016/00253227(90)90114-Y.

Font, J., P. Puig, J. Salat, A. Palanques, and M. Emelianov (2007), Sequence of hydrographic changes in the NW Mediterranean deep water due to exceptional winter 2005, Sci. Mar., 72, 339-346.

Fu, L.-L., D. B. Chelton, P.-Y. Le Traon, and R. Morrow (2010), Eddy dynamics from satellite altimetry, Oceanography, 23(4), 14-25, doi: $10.5670 /$ oceanog. 2010.02 .

García, M. A. (1982), Aproximación al comportamiento estadístico del viento en el delta del Ebro. Estudio de la velocidad escalar, Invest. Pesq., 46(3), 349-377.

García-Lafuente, J. M., J. L. López-Jurado, N. Cano-Lucaya, M. VargasYáñez, and J. Aguiar-Garcia (1995), Circulation of water masses through the Ibiza Channel, Oceanol. Acta, 18(2), 245-254.

Garreau, P., V. Garnier, and A. Schaeffer (2011), Eddy resolving modelling of the Gulf of Lions and Catalan Sea, Ocean Dyn., 61(7), 991-1003, doi:10.1007/s10236-011-0399-2.

General Bathymetric Chart of the Oceans (GEBCO) (2003), The GEBCO Digital Atlas, Brit. Oceanogr. Data Centre, Liverpool, U.K.

Heslop, E. E., S. Ruiz, J. T. Allen, J. L. López-Jurado, L. Renault, and J. Tintoré (2012), Autonomous underwater gliders monitoring variability at "choke points" in our ocean system: A case study in the Western Mediterranean Sea, Geophys. Res. Lett., 39, L20604, doi:10.1029/ 2012 GL053717.

Holloway, G. (2008), Observing global ocean topostrophy, J. Geophys. Res., 113, C07054, doi:10.1029/2007JC004635.

Holloway, G., A. Nguyen, and Z. Wang (2011), Oceans and ocean models as seen by current meters, J. Geophys. Res., 116, C00D08, doi:10.1029/ 2011JC007044.

Hu, Z. Y., A. M. Doglioli, A. A. Petrenko, P. Marsaleix, and I. Dekeyser (2009), Numerical simulations of eddies in the Gulf of Lion, Ocean Modell., 28(4), 203-208, doi:10.1016/j.ocemod.2009.02.004.

Hu, Z. Y., A. A. Petrenko, A. M. Doglioli, and I. Dekeyser (2011), Study of a mesoscale anticyclonic eddy in the western part of the Gulf of Lion, J. Mar. Syst., 88(1), 3-11, doi:10.1016/j.jmarsys.2011.02.008.

Jansá, A. (1987), Distribution of the Mistral: A satellite observation, Meteorol. Atmos. Phys., 36(1-4), 201-214, doi:10.1007/BF01045149.

Jordi, A., and S. Hameed (2009), Influence of the Icelandic low on the variability of surface air temperature in the Gulf of Lion: Implications for intermediate water formation, J. Phys. Oceanogr., 39(12), 3228-3232, doi:10.1175/2009JPO4194.1.

Jordi, A., G. Basterretxea, and S. Anglès (2009), Influence of ocean circulation on phytoplankton biomass distribution in the Balearic Sea: Study based on sea-viewing wide field-of-view sensor and altimetry satellite data, J. Geophys. Res., 114, C11005, doi:10.1029/ 2009JC005301.

Kalnay, E., et al. (1996), The NCEP/NCAR 40-year reanalysis project, Bull. Am. Meteorol. Soc., 77, 437-471, doi:10.1175/1520-0477 (1996) $077<0437:$ TNYRP $>2.0 . \mathrm{CO} ; 2$

La Violette, P. E., J. Tintoré, and J. Font (1990), The surface circulation of the Balearic Sea, J. Geophys. Res., 95(C2), 1559-1568, doi:10.1029/ JC095iC02p01559.
Larnicol, G., P.-Y. Le Traon, N. Ayoub, and P. De Mey (1995), Mean sea level and surface circulation variability of the Mediterranean Sea from 2 years of TOPEX/POSEIDON altimetry, J. Geophys. Res., 100, 25,16325,177, doi: 10.1029/95JC01961.

Larnicol, G., N. Ayoub, and P.-Y. Le Traon (2002), Major changes in Mediterranean Sea level variability from 7 years of TOPEX/Poseidon and ERS-1/2 data, J. Mar. Syst., 33-34, 63-89, doi:10.1016/S09247963(02)00053-2.

Lloret, J., J. Palomera, J. Salat, and I. Sole (2004), Impact of freshwater input and wind on landings of anchovy (Engraulis encrasicolus) and sardine (Sardina pilchardus) in shelf waters surrounding the Ebre (Ebro) River delta (north-western Mediterranean), Fish. Oceanogr., 13(2), 102110, doi:10.1046/j.1365-2419.2003.00279.x.

López García, M. J., C. Millot, J. Font, and E. García-Ladona (1994), Surface circulation variability in the Balearic Basin, J. Geophys. Res., 99(C2), 3285-3296, doi:10.1029/93JC02114.

López-Jurado, J. L., C. Gonzáles-Pola, and P. Vélez-Belchí (2005), Observation of an abrupt disruption of the long-term warming trend at the Balearic Sea, western Mediterranean, in summer 2005, Geophys. Res. Lett., 32, L24606, doi: 10.1029/2005GL024430.

López García, M. J., and A. M. Camarasa Belmonte (2011), Recent trends of SST in the Western Mediterranean basins from AVHRR Pathfinder data (1985-2007), Global Planet. Change, 78(3-4), 127-136, doi:10.1016/j.gloplacha.2011.06.001.

Lorenzo-Lacruz, J., S. M. Vicente-Serrano, J. I. López-Moreno, E. MoránTejeda, and J. Zabalza (2012), Recent trends in Iberian streamflows (19452005), J. Hydrol., 414-415, 463-475, doi:10.1016/j.jhydrol.2011.11.023.

Marshall, J., and F. Schott (1999), Open-ocean convection: Observations, theory, and models, Rev. Geophys., 37(1), 1-64, doi:10.1029/98RG02739.

Masó, M., and J. Tintoré (1991), Variability of the shelf water off the northeast Spanish coast, J. Mar. Syst., 1(4), 441-450, doi:10.1016/09247963(91)90008-I.

Masó, M., P. E. La Violette, and J. Tintoré (1990), Coastal flow modification by submarine canyons along the NE Spanish coast, Sci. Mar., 54, $343-348$

Mason, E. (2009), High-resolution modelling of the Canary Basin oceanic circulation, PhD thesis, 245 pp., Univ. de Las Palmas de Gran Canaria Canary Islands, Spain.

Mediterranean Ocean Convective experiment (MEDOC) (1970), Observation of formation of deep water in the Mediterranean Sea, Nature, 227, 1037-1040.

Millot, C. (1999), Circulation in the Western Mediterranean Sea, J. Mar. Syst., 20(1-4), 423-442, doi:10.1016/S0924-7963(98)00078-5.

Millot, C., and I. Taupier-Letage (2005), Circulation in the Mediterranean Sea, in The Mediterranean Sea, Handbook of Environmental Chemistry, vol. $5 K$, edited by Saliot, A. pp. 29-66, Springer, Berlin, doi:10.1007/ b107143.

Molcard, A., N. Pinardi, M. Iskandarani, and D. B. Haidvogel (2002), Wind driven general circulation of the Mediterranean Sea simulated with a Spectral Element Ocean Model, Dyn. Atmos. Oceans, 35(2), 97-130, doi:10.1016/S0377-0265(01)00080-X.

Monserrat, S., J. L. López-Jurado, and M. Marcos (2008), A mesoscale index to describe the regional circulation around the Balearic Islands, $J$. Mar. Syst., 71(3-4), 413-420, doi:10.1016/j.jmarsys.2006.11.012.

Olita, A., A. Ribotti, R. Sorgente, L. Fazioli, and A. Perilli (2011), SLAchlorophyll-a variability and covariability in the Algero-Provençal Basin (1997-2007) through combined use of EOF and wavelet analysis of satellite data, Ocean Dyn., 61(1), 89-102, doi:10.1007/s10236-0100344-9.

Onken, R., A. Álvarez, V. Fernández, G. Vizoso, G. Basterretxea, J. Tintoré, P. J. Haley Jr, andE. Nacini (2008), A forecast experiment in the Balearic Sea, J. Mar. Syst., 71(1-2), 70-39, doi:10.1016/j.jmarsys.2007.05.008.

Palomares Losada, A. M. (1999), Analysis of the meteorological synoptic situations that affect the Straits of Gibraltar and their influence on the surface wind, Bol. Inst. Esp. Oceanogr., 15(1-4), 81-90.

Pascual, A., B. Buongiorno Nardelli, G. Larnicol, M. Emelianov, and D. Gomis (2002), A case of an intense anticyclonic eddy in the Balearic Sea (western Mediterranean), J. Geophys. Res., 107(C11), 3183, doi:10.1029/ 2001JC000913.

Pascual, A., M.-I. Pujol, G. Larnicol, P.-Y. Le Traon, and M.-H. Rio (2007), Mesoscale mapping capabilities of multisatellite altimeter missions: First results with real data in the Mediterranean Sea, J. Mar. Syst., 65, 190-211, doi:10.1016/j.jmarsys.2004.12.004.

Pascual, A., S. Ruiz, and J. Tintoré (2010), Combining new and conventional sensors to study the Balearic Current, Sea Tech., 51(7), 32-36. 
Perkins, H., and P. Pistek (1990), Circulation in the Algerian Basin during June 1986, J. Geophys. Res., 95(C2), 1577-1585, doi:10.1029/ JC095iC02p01577.

Pinot, J.-M., and A. Ganachaud (1999), The role of winter intermediate waters in the spring-summer circulation of the Balearic Sea: 1. Hydrography and inverse box modeling, J. Geophys. Res., 104(C12), 29,84329,864, doi:10.1029/1999JC900202.

Pinot, J.-M., A. Álvarez, V. Fernández, and M. Riera (1999), The role of winter intermediate waters in the spring-summer circulation of the Balearic Sea: 2. A sensitivity numerical study, J. Geophys. Res., 104(C12), 29,865-29,884, doi:10.1029/1999JC900071.

Pinot, J.-M., J. L. López-Jurado, and M. Riera (2002), The CANALES experiment (1996-1998). Interannual, seasonal, and mesoscale variability of the circulation in the Balearic Channels, Prog. Oceanogr., 55(3-4), 335-370, doi:10.1016/S0079-6611(02)00139-8.

Poulain, P.-M., M. Menna, and E. Mauri (2012a), Surface geostrophic circulation of the Mediterranean Sea derived from drifter and satellite altimeter data, J. Phys. Oceanogr., 42(6), 973-990, doi:10.1175/JPO-D-11-0159.1.

Poulain, P.-M., R. Gerin, M. Rixen, P. Zanasca, J. Teixeira, A. Griffa, A. Molcard, M. De Marte, and N. Pinardi (2012b), Aspects of the surface circulation in the Liguro-Provençal basin and Gulf of Lion as observed by satellite-tracked drifters (2007-2009), Bol. Geofis. Teor. Appl., 53(2), 261-279, doi:10.4430/bgta0052.

Preisendorfer, R. W. (1988), Principal Component Analysis in Meteorology and Oceanography, 425 pp., Elsevier, Oxford, U. K.

Puillat, I., I. Taupier-Letage, and C. Millot (2002), Algerian eddies lifetime can near 3 years, J. Mar. Syst., 31(4), 245-259, doi:10.1016/S09247963(01)00056-2.

Pujol, M.-I., and G. Larnicol (2005), Mediterranean sea eddy kinetic energy variability from 11 years of altimetric data, J. Mar. Syst., 58(3-4), 121142, doi:10.1016/j.jmarsys.2005.07.005.

Renault, L., T. Oguz, A. Pascual, G. Vizoso, and J. Tintoré (2012), Surface circulation in the Alborán Sea (western Mediterranean) inferred from remotely sensed data, J. Geophys. Res., 117, C08009, doi:10.1029/ 2011JC007659

Ribó, M., P. Puig, A. Palanques, and C. Lo Iacono (2011), Dense shelf water cascades in the Cap de Creus and Palamós submarine canyons during winters 2007 and 2008, Mar. Geol., 284(1-4), 175-188, doi:10.1016/ j.margeo.2011.04.001.

Rio, M.-H., P.-M. Poulain, A. Pascual, E. Mauri, G. Larnicol, and R. Santoleri (2007), A mean dynamic topography of the mediterranean sea computed from altimetric data, in-situ measurements and a general circulation model, J. Mar. Syst., 65(1-4), 484-508, doi:10.1016/j.jmarsys.2005.02.006.

Rixen, M., et al. (2005), The Western Mediterranean Deep Water: A proxy for climate change, Geophys. Res. Lett., 32, L12608, doi:10.1029/ 2005 GL022702.

Robinson, A. R., W. G. Leslie, A. Theocharis, and A. Lascaratos (2001), Mediterranean Sea circulation, in Encyclopedia of Ocean Sciences, vol. 3, edited by J. H. Steele, S. A. Thorpe, and K. K. Turekian, pp. 16891705, Academic Press, London, doi:10.1006/rwos.2001.0376.

Rubio, A., P. A. Arnau, M. Espino, M. M. Flexas, G. Jordà, J. Salat, J. Puigdefâbregas, and A. Sánchez-Arcilla (2005), A field study of the behaviour of an anticyclonic eddy on the Catalan continental shelf (NW Mediterranean), Prog. Oceanogr., 66(2-4), 142-156.

Rubio, A., B. Barnier, G. Jordà, M. Espino, and P. Marsaleix (2009), Origin and dynamics of mesoscale eddies in the Catalan Sea (NW Mediterranean): Insight from a numerical model study, J. Geophys. Res., 114, C06009, doi:10.1029/2007JC004245.
Ruiz, S., A. Pascual, B. Garau, Y. Faugère, A. Alvarez, and J. Tintoré (2009), Mesoscale dynamics of the Balearic Front, integrating glider, ship and satellite data, J. Mar. Syst., 78(suppl.), S3-S16, doi:10.1016/ j.jmarsys.2009.01.007.

Salat, J., et al. (2002), Seasonal changes of water mass structure and shelf slope exchanges at the Ebro Shelf (NW Mediterranean), Cont. Shelf Res., 22(2), 327-348, doi:10.1016/S0278-4343(01)00031-0.

Salat, J., P. Puig, and M. Latasa (2010), Violent storms within the Sea: Dense water formation episodes in the NW Mediterranean, Adv. Geosci., 26, 53-59, doi:10.5194/adgeo-26-53-2010.

Schroeder, K., V. Taillandier, A. Vetrano, and G. P. Gasparini (2008), The circulation of the western Mediterranean Sea in spring 2005 as inferred from observations and from model outputs, Deep-Sea Res., 55(8), 947965, doi:10.1016/j.dsr.2008.04.003.

Send, U., C. Mertens, and J. Font (1996), Recent observation indicates convection's role in deep water circulation, Eos Trans. $A G U, 77(7), 61-65$, doi:10.1029/96EO00040.

Send, U., J. Font, G. Krahmann, C. Millot, M. Rhein, and J. Tintoré (1999), Recent advances in observing the physical oceanography of the western Mediterranean Sea, Prog. Oceanogr., 44(1-3), 37-64, doi:10.1016/ S0079-6611(99)00020-8.

Smith, S. D. (1988), Coefficients for sea surface wind stress, heat flux, and wind profiles as a function of wind speed and temperature, J. Geophys. Res., 93(C12), 15,467-15,472, doi:10.1029/JC093iC12p15467.

Struglia, M. V., A. Mariotti, and A. Filograsso (2004), River discharge into the Mediterranean Sea: Climatology and aspects of the observed variability, J. Clim., 17(24), 4740-4751, doi:10.1175/JCLI-3225.1.

Testor, P., and J.-C. Gascard (2006), Post-convection spreading phase in the Northwestern Mediterranean Sea, Deep-Sea Res., 53(5), 869-893, doi:10.1016/j.dsr.2006.02.004.

Testor, P., U. Send, J.-C. Gascard, C. Millot, I. Taupier-Letage, and K. Béranger (2005), The mean circulation of the southwestern Mediterranean Sea: Algerian gyres, J. Geophys. Res., 110, C11017, doi:10.1029/ 2004JC002861.

Ulses, C., C. Estournel, P. Puig, X. Durrieu de Madron, andP. Marsaleix (2008), Dense shelf water cascading in the northwestern Mediterranean during the cold winter 2005: Quantification of the export through the Gulf of Lion and the Catalan margin, Geophys. Res. Lett., 35, L07610, doi: 10.1029/2008GL033257.

Vargas-Yáñez, M., P. Zunino, K. Schroeder, J. L. López-Jurado, F. Plaza, M. Serra, C. G. Castro, M. C. García-Martínez, F. Moya, and J. Salat (2012), Extreme western intermediate water formation in winter 2010, J. Mar. Syst., 105-108, 52-59, doi:10.1016/j.jmarsys.2012.05.010.

Vidal-Vijande, E. (2012), Analysis of Mediterranean ocean variability using five numerical simulations, $\mathrm{PhD}$ thesis, 235 pp., Univ. de Las Palmas de Gran Canaria, Canary Islands, Spain.

von Storch, H., and F. W. Zwiers (1999), Statistical Analysis in Climate Research, 496 pp., Cambridge Univ. Press, Cambridge, U. K.

Xing, J., and A. M. Davies (2002a), Influence of topographic features and along shelf flow upon the Ebro plume, Cont. Shelf Res., 22(2), 199-227, doi:10.1016/S0278-4343(01)00054-1.

Xing, J., and A. M. Davies (2002b), Influence of shelf topography upon along shelf flow and across shelf exchange in the region of the Ebro Delta, Cont. Shelf Res., 22(10), 1447-1475, doi:10.1016/S0278-4343(02)00020-1.

Zecchetto, S., and F. De Biasio (2007), Sea surface winds over the Mediterranean Basin from satellite data (2000-04): Meso- and local-scale features on annual and seasonal time scales, J. Appl. Meteorol. Climatol., 46, 814-827, doi:10.1175/JAM2498.1. 